\title{
GEOENGINEERING: OCEAN IRON FERTILISATION AND THE LAW OF THE SEA
}

\author{
LLM RESEARCH PAPER \\ LAWS 528: LAW OF THE SEA
}

\section{FACULTY OF LAW}

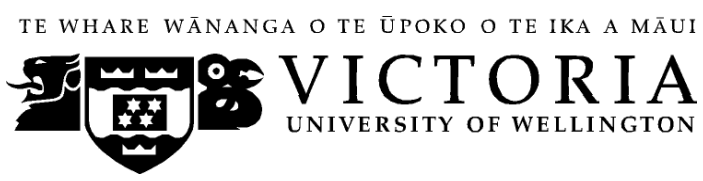

2014 


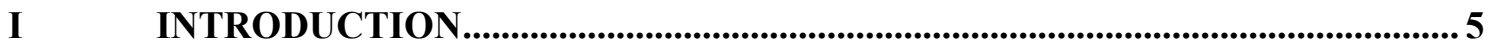

II PROBLEM DOMAIN DESCRIPTION AND CONTEXT - CLIMATE

CHANGE AND GEOENGINEERING .......................................................................... 7

A The Science of Climate Change and its Effects ................................................................ 7

B What is Geoengineering and why is it Considered? .............................................. 11

1 Operation Popeye and the Environmental Modification Treaty of

1976

$2 \quad$ Carbon Dioxide Removal ..................................................................................... 16

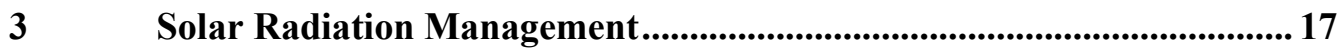

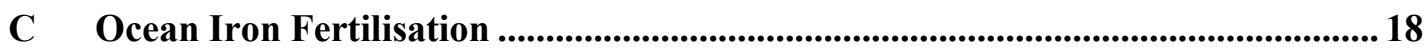

1 The Potential Benefits of Ocean Iron Fertilisation ...................................... 18

2 The Potential Harms of Ocean Iron Fertilisation ........................................ 19

D Social and Ethical Implications and the Moral Hazard of Geoengineering .......... 20

III THE LAW OF THE SEA AND OCEAN IRON FERTILISATION - THE CURRENT REGULATORY REGIME, EVOLUTION AND ANALYSIS ......... 21

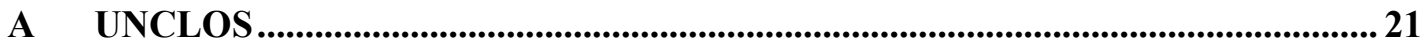

B The 1972 Convention on the Prevention of Marine Pollution by Dumping of Wastes and Other Matter and the 1996 Protocol to the 1972 Convention on the Prevention of Marine Pollution by Dumping of Wastes and Other Matter

1 The Introduction of Ocean Iron Fertilisation to the Scientific Group and Consultative Meeting of the Parties under the London Convention................ 36

2 The 2007 "Statement of Concern" 39

C The 2008 and 2010 Resolutions.

1 Hard Law and Soft Law - the Relevance of the 2008 and 2010

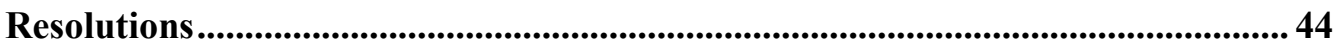

D The Precautionary Principle and the Convention on Biological Diversity ............ 48

E Conclusion on Ocean Iron Fertilisation under the Current Law ..........................50

IV EFFECTIVENESS OF THE LAW AT REGULATING OCEAN IRON FERTILISATION - CONTEMPORARY EXAMPLES....................................51

A The LOHAFEX Experiment ............................................................................................. 51

B The Haida Salmon Restoration Corporation Case ..................................................5 52 


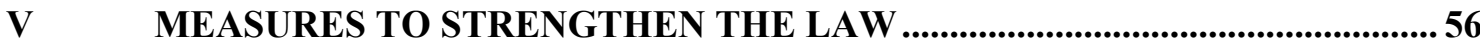

A Fragmentation of Global Governance Architectures ...............................................56

B Option Proposed by Australia and New Zealand....................................................5 57

C Strengthening Domestic Law ...................................................................................... 58

D Economic Considerations ...............................................................................................5 59

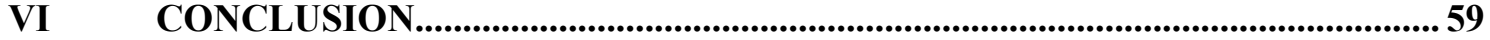

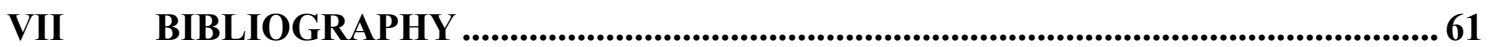




\begin{abstract}
Climate change mitigation is one the greatest challenges facing humankind. Recent attempts at reducing carbon emissions have stalled. Various proposals have been made that aim to reduce the levels of atmospheric carbon dioxide through geoengineering. One such technique is ocean iron fertilisation. This paper examines the current state of international law surrounding geoengineering practices involving the sea, with a predominant focus on ocean iron fertilisation, to evaluate the law's appropriateness and effectiveness at regulating this conduct. This paper concludes that the current law lacks certainty and clarity. It proposes that the law would be more effective through a legally binding amendment to the London Convention and Protocol, stronger domestic legislation and the removal of economic incentives.
\end{abstract}

\title{
Word length
}

The text of this paper (excluding abstract, table of contents, footnotes and bibliography) comprises approximately 14,648 words.

\section{Subjects and Topics}

Law of the Sea

United Nations Convention on the Law of the Sea

London Convention

London Protocol

Geoengineering

Ocean iron fertilisation 


\section{Introduction}

It is difficult to overstate the importance of the world's oceans. Modern science tells us that life first began in the oceans. ${ }^{1}$ It is suggested that hydrothermal vents deep beneath the surface provided the environment for the formation of amino acids, the precursors to carbon-based life forms. ${ }^{2}$ The first land animals crawled from this primordial soup while millions of years later, others re-entered the sea to become the cetaceans that are present today. ${ }^{3}$ Humankind's development has been reliant on the sea, most notably as an important source of food. The sea is a vital source of protein for millions of people around the world. The oceans also are the main conduit for commerce, the overwhelming majority of the world's trade is made possible through transportation of goods across the seas.

The aforementioned uses are well-known. People eat fish and rely on goods transported from overseas markets. In short they have a direct connection to the sea in these respects. However the ocean fulfils another crucial role which is vital to the regulation of the Earth's life sustaining processes. The Intergovernmental Panel on Climate Change (IPCC), in its 2013 report, has observed that "the ocean influences climate by storing and transporting large amounts of heat, freshwater, and carbon, and by exchanging these properties with the atmosphere." ${ }^{4}$ Oceans naturally play a large role in the planet's climate and temperature regulation, oxygen generation and carbon dioxide absorption processes. The IPCC reports that approximately $93 \%$ of the excess heat energy produced and stored by the Earth over the last 50 years is contained in the ocean. ${ }^{5}$

\footnotetext{
${ }^{1}$ Gunther Wachtershauser "Evolution of the first metabolic cycles" (1990) 87 Proc. Natl. Acad. Sci. USA 200 .

${ }^{2}$ At 200.

${ }^{3}$ See for example Donald R. Prothero and Scott E. Foss The Evolution of Artiodactyls (The Johns Hopkins University Press, Baltimore, 2007).

4 Intergovernmental Panel on Climate Change "Climate Change 2013: The Physical Basis. Contribution of Working Group I to the Fifth Assessment Report of the Intergovernmental Panel on Climate Panel on Climate Change" (2013) Report, at 260. [IPCC AR5 Report WG1].

${ }^{5}$ At 260 .
} 
Few would disagree that the world's reliance on fossil fuels as a driver of economic growth and prosperity has meant that anthropogenic climate change has become one of the largest issues facing humankind today. Various proposals aimed at addressing climate change through geoengineering have been put forward with perhaps the most contentious being ocean fertilisation. Ocean fertilisation attempts to modify the environment through the addition of matter such as iron into the sea. The iron compounds are designed to create or stimulate phytoplankton blooms. The introduction occurs in High Nutrient Low Chlorophyll (HNLC) regions where it is theorised that the increase in phytoplankton will remove carbon dioxide from the atmosphere through the process of photosynthesis. ${ }^{6}$ Most of the HNLC regions are on the high seas, in areas beyond national jurisdiction. It is unsurprising then that ocean fertilisation involves the intersection of various bodies of law such as the law of the sea and climate change or environmental law. The main international instruments applicable are the United Nations Convention on the Law of the $\mathrm{Sea}^{7}$ ("UNCLOS"), the 1972 Convention on the Prevention of Marine Pollution by Dumping of Wastes and Other Matter ("London Convention"/"The Convention") and the 1996 Protocol to the 1972 Convention on the Prevention of Marine Pollution by Dumping of Wastes and Other Matter" ("London Protocol"/"The Protocol”). However the technological advances in the area of geoengineering post-date the creation of these instruments and their applicability and efficacy as a regulatory regime may be questioned.

This paper examines the current state of international law surrounding geoengineering practices involving the sea, with a predominant focus on ocean iron fertilisation, to evaluate

\footnotetext{
$\overline{6}$ Timothy M. Lenton and Naomi E. Vaughan “A Review of Climate Geoengineering Proposals” (2011) 109 Climatic Change at 755 .

${ }^{7}$ United Nations Convention on the Law of the Sea 1833 UNTS 3 (opened for signature 10 December 1982 , entered into force 16 November 1994). [UNCLOS].

81972 Convention on the Prevention of Marine Pollution by Dumping of Wastes and Other Matter 1046 UNTS 120 (opened for signature 29 December 1972, entered into force 30 August 1975).

91996 Protocol to the 1972 Convention on the Prevention of Marine Pollution by Dumping of Wastes and Other Matter 2006 ATS 11 (opened for signature 7 November 1996, entered into force 24 March 2006).
} 
the law's appropriateness and effectiveness at regulating these practices. This paper is structured into 6 main parts. Part 2 describes the climate change problem and the science behind climate change before moving on to consider geoengineering practices with a focus on ocean iron fertilisation. Part 3 critically evaluates the international law relevant to the sea and ocean iron fertilisation to determine its appropriateness and effectiveness at proscribing this conduct. Part 4 examines two projects involving ocean iron fertilisation to analyse and explore the efficacy of the relevant law at the international and domestic level. Part 5 considers some options available that may assist in strengthening the law relating to ocean iron fertilisation. Part 6 delivers the conclusions.

\section{Problem Domain Description and Context - Climate Change and Geoengineering}

The legal issues relating to geoengineering governance cannot be fully appreciated without first locating the problem and placing it within its context. It is therefore necessary to consider the problems that geoengineering purports to address. This in turn requires a description of those problems themselves. The following discussion outlines the science behind climate change and geoengineering by looking at the various geophysical and biological mechanisms involved. It attempts to give a basic overview only and omits much of the technical detail.

\section{A The Science of Climate Change and its Effects}

The weather and the climate are two different things. The weather refers to the atmospheric conditions at a particular point in time and space and is concerned with key meteorological elements such as pressure, humidity and temperature. ${ }^{10}$ Climate however, is generally defined in statistical terms relating to the mean and variability of relevant quantities, such

${ }^{10}$ IPCC AR5 Report WG1 at 123. 
as surface temperature, over time. ${ }^{11}$ The timescale in climate change refers to decades or centuries.

The Earth's climate system is driven by solar radiation from the Sun. In order for the system to be in equilibrium, the incoming solar shortwave radiation (SWR) must be equal to the outgoing radiation. Scientists have postulated this to be the case due to the relatively consistent surface temperatures over the preceding centuries. ${ }^{12}$ A portion of the SWR that reaches the Earth is reflected back into space by the clouds, gases and the Earth's surface itself. The reflectivity of the Earth is called its albedo. The majority of the incident radiation travels through the atmosphere and is absorbed thereby increasing the surface temperature. ${ }^{13}$ The atmospheric temperature is more accurately known as thermal radiation. While much of the thermal radiation escapes into space, a portion of the thermal radiation emitted from the surface of the Earth is absorbed by atmospheric greenhouse gases and clouds. ${ }^{14}$ The reduction in escaping thermal radiation adds to the incoming solar irradiance and causes both the atmosphere and the Earth to warm.

Carbon dioxide $\left(\mathrm{CO}_{2}\right)$ is the main greenhouse gas. The atmospheric concentration of $\mathrm{CO}_{2}$ has increased dramatically in the last one hundred years from a pre-industrial level of 280 parts per million (ppm) to current day levels greater than $380 \mathrm{ppm} .{ }^{15} \mathrm{It}$ is widely accepted that this is a direct "result of anthropogenic emissions from fossil fuel combustion and deforestation." 16 The elevated $\mathrm{CO}_{2}$ concentrations have reduced the flux of outgoing radiation emitted into space. ${ }^{17}$ Studies have supported the theories laid down by geophysics

\footnotetext{
${ }^{11}$ At 123 .

12 At 126.

13 The Royal Society “Geoengineering the Climate: Science Governance and Uncertainty” (2009) Report at

2. [Royal Society].

14 At 2.

${ }^{15}$ Vaughan and Lenton, above n 6, at 748.

${ }^{16}$ At 748.

${ }^{17}$ At 748 .
} 
by showing an average increase of about one degree Celsius in the last 130 years ${ }^{18}$ which has led to the IPCC declaring that it is "virtually certain that globally the troposphere has warmed since the mid- $20^{\text {th }}$ century." 19 Looking to the future, the IPCC concludes that: ${ }^{20}$

Continued emissions of greenhouse gases will cause further warming and changes in components of the climate system. Limiting change will require substantial and sustained reductions of greenhouse gas emissions.

The United Nations Secretary-General put it in more direct terms, linking climate change and its consequences with the oceans and seas: ${ }^{21}$

Climate change continues to have a significant impact on the oceans and the lives of people that depend on the sea. Observations of increases in global average air and ocean temperatures, widespread melting of snow and ice, and rising global average sea levels conclusively indicate that the world is already warming in response to past greenhouse gas emissions, and are evidence of a warmer world in the future.

The Secretary-General continued on to identify further effects, some of which have already begun to occur, noting that: ${ }^{22}$

Climate change is already affecting the seasonality of particular biological processes, radically altering marine and freshwater food webs, with unpredictable consequences for fish production. Differential warming...will affect the intensity, frequency and seasonality of climate patterns... and thus impact the stability of marine and freshwater resources adapted to or affected by these patterns and events.

Other effects of climate change are well-documented. Water and food insecurity and rising sea levels are some of the most discussed effects, yet the impact of climate change reaches

\footnotetext{
${ }^{18}$ IPCC, above $\mathrm{n} 4$, at 5.

${ }^{19}$ At 5 .

${ }^{20}$ At 19 .

${ }^{21}$ Oceans and the Law of the Sea - Report of the Secretary-General, $63^{\text {rd }}$ sess, Agenda Item 73(a), UN DOC A/63/63/Add. 1 (29 August 2008) at [259].

${ }^{22}$ Oceans and the Law of the Sea-Report of the Secretary-General, 63 ${ }^{\text {rd }}$ sess, Agenda Item 73(a), UN DOC A/63/63/Add. 1 (29 August 2008) at [261].
} 
further than that. Extreme climatic events will increase death tolls amongst the elderly through an increase in heatwaves while vector-borne diseases will spread in scope and reach. ${ }^{23}$ Population growth and migration will increase leading to the intensification of desirable land areas as people abandon flooded or arid environments. ${ }^{24}$ This will add to already increasing pressure and competition for resources.

Climate change has even been identified by scholars as one of the anticipated maritime security challenges facing the world, and indeed coastal states such as Australia and New Zealand. ${ }^{25}$ The potential impact on the marine environment could be substantial "extending from the melting of the polar ice caps, resulting in the appearance of open water across the Arctic Ocean and significant icebergs throughout the Southern Ocean, to the redistribution of some fish stocks as their habitats change." 26

Climate change's impact on economics is significant. Carbon dioxide emissions are the trade-off for cheap energy, and commodities such beef, mutton, dairy and rice cannot be produced without emitting another significant greenhouse gas, methane. ${ }^{27}$ Climate change has been referred to as the "mother of all externalities". ${ }^{28}$ A multitude of studies, despite the use of differing models, all show a significant reduction in gross domestic product (GDP) due to climate change. However this is not a globally uniform result, "the emissions of greenhouse gases are predominantly from high-income countries while the negative

\footnotetext{
${ }^{23}$ Anthony Costello and others "Managing the Health Effects of Climate Change" (2009) 373 The Lancet at 1693.

${ }^{24}$ At 1707.

${ }^{25}$ Donald R. Rothwell "Maritime Security in the Twenty-First Century: Contemporary and Anticipate Challenges for Australia and New Zealand" in Natalie Klein, Joanna Mossop and Donald R. Rothwell (eds) Maritime Security: International Law and Policy Perspectives from Australia and New Zealand (Routledge, Oxon, 2010) 242 at 253.

${ }^{26}$ At 253.

${ }^{27}$ Richard S. J. Tol "The Economic Effects of Climate Change" (2009) 23 Journal of Economic Perspectives 29 at 29.

${ }^{28}$ At 29.
} 
effects of climate change are predominantly in low-income countries." ${ }^{29}$ Various economic aspects of geoengineering and implications for governance will be discussed later on in this paper. It is of no real surprise that the complicated and inextricably linked problems associated with climate change, place a heavy strain on the law and the legal instruments tasked with regulating this contemporary issue.

\section{$B \quad$ What is Geoengineering and why is it Considered?}

It is trite to say that the solution to the Earth's climate change woes is through the abatement of greenhouse gases. In a less complex world, this would be the ideal approach. However the problem is one of collective action and efforts to reduce greenhouse gas risks have been disappointing so far. ${ }^{30}$ This disappointment has led to a second legitimate category of action, that is, the adaptation of society and ecosystems to the developing climate. ${ }^{31}$ The third category of action involves proposals, some of which have already been attempted in some form, to "intentionally intervene on massive scales in global physical, chemical and biological systems in order to counterbalance climate change." ${ }^{32}$ What was once only in the realm of science fiction has become a beckoning reality. ${ }^{33}$ The first and third categories of action fit the definition of "mitigation" given by the IPCC as "a human intervention to reduce the sources or enhance the sinks of greenhouse gases." ${ }^{\prime 34}$ The second category fits the definition of "adaptation" which is defined as the initiatives and measures taken to reduce the vulnerability of natural and human systems against actual or expected climate

\footnotetext{
${ }^{29}$ At 36.

${ }^{30}$ Jesse L. Reynolds and Floor Fleurke "Climate Engineering Research: A Precautionary Response to Climate Change?" (2013) 2 CCLR 101 at 101.

${ }^{31}$ At 101.

${ }^{32}$ At 101.

${ }^{33}$ See Iain M. Banks The Algebraist (Orbit, UK, 2004).

${ }^{34}$ IPCC, above n 4, at 1458.
} 
change events. ${ }^{35}$ Examples of adaptation initiatives include raising coastal dikes or the substitution of temperature-shock resistant plants for sensitive ones. ${ }^{36}$

There is no single definition of geoengineering that has been agreed upon by the research, policy and legal communities. The IPCC has recently broadened its definition stating that "geoengineering refers to a broad set of methods and technologies that aim to deliberately alter the climate system in order to alleviate the impacts of climate change." ${ }^{37}$

Geoengineering may be considered as a legitimate course of action for various reasons. Although GDP per capita has doubled over the last 45 years, advances in income and health indicators have also been accompanied by a depletion of natural capital and various threats to the ecosystem. ${ }^{38}$ Scholarship has shown that the world has a finite quantity of natural capital, and by definition, the source and sink resources required by the world's economy for continual growth are limited so that at certain thresholds, demand would exceed supply thereby causing negative social and environmental consequences. ${ }^{39}$ Affluent nations have set consumption benchmarks which others aspire to, "it is the increasing convergence of aspirations on high consumption patterns that continue to drive upward movements in consumption. ${ }^{40}$ The convergence of aspirations and resultant growing consumption has led to the breaching of planetary and regional boundaries for climate change, biodiversity loss and nitrogen pollution, as well as placing pressure on land use and causing ocean acidification. ${ }^{41}$

35 Olivier Boucher and others "Rethinking Climate Engineering Categorization in the Context of Climate Change Mitigation and Adaptation" (2013) WIREs Clim Change 2 at 2.

${ }^{36}$ At 2 .

${ }^{37}$ IPCC, above n 4, at 1454.

${ }^{38}$ Jules Pretty "The Consumption of a Finite Planet: Well-Being, Convergence, Divergence and the Nascent Green Economy" (2013) 55 Environ Resource Econ 475 at 476.

${ }^{39}$ At 476.

${ }^{40}$ At 481 .

${ }^{41}$ At 487. 
One could be forgiven for despairing at this gloomy picture. The evidence shows that both aggregate consumption and world population are set to increase. The two challenges then are to stabilise emissions and atmospheric conditions and to stabilise them at a low enough level to limit severe damage to the ecosystem and human health. ${ }^{42}$ The United Nations Framework Convention on Climate Change ${ }^{43}$ (UNFCCC) is a multilateral forum designed with the specific intent of addressing climate change. Article 2 of the Convention describes its ultimate objective whilst recognising the importance of economic development: ${ }^{44}$

The ultimate object of this Convention...is to achieve...stabilization of greenhouse gas concentrations in the atmosphere at a level that would prevent dangerous anthropogenic interference with the climate system. Such a level should be achieved...to ensure food production is not threatened and to enable economic development to proceed in a sustainable manner.

The UNFCCC offers mechanisms that can modify the incentive structures of private and public entities, and this can be seen through the workings of the Kyoto Protocol. ${ }^{45}$ Commentators characterise the negotiations on climate change under the UNFCCC as being increasingly burdened by the gap between the low political will to engage in emissions mitigation and the significant mitigation levels required to limit global warming to an increase of only two degrees Celsius. ${ }^{46}$ The prevailing view that has developed is that mitigation measures will be insufficient by themselves. The convergence of aspirations and growing consumption when coupled with the back-peddling of various States with regard to emissions targets manifests itself in the view that geoengineering has become a legitimate tool in the portfolio of climate change mitigation options. In short, the argument

\footnotetext{
42 At 488.

${ }^{43} 1992$ United Nations Framework Convention in Climate Change 1771 UNTS 107 (opened for signature 9 May 1992, entered into force 21 March 1994). [UNFCCC]; 1997 Kyoto Protocol to the UN Framework Convention on Climate Change 2303 UNTS 148 (opened for signature 11 December 1997, entered into force 16 February 2005).

${ }^{44}$ UNFCCC, art 2.

${ }^{45}$ Matthias Honegger and Kushini Sugathapala and Axel Michaelowa "Tackling Climate Change: Where can the Generic Framework be Located?"(2013) 2 CCLR 125 at 130.

${ }^{46}$ At 125.
} 
can be reduced to the following proposition, in order to keep consuming, and living, we must geoengineer.

\section{Operation Popeye and the Environmental Modification Treaty of 1976}

In fact pages have already been torn from science fiction and rendered as science fact in what is arguably the most prominent use of geoengineering to date. This project, dubbed "Operation Popeye" was undertaken by the U.S. Military and involved the deliberate seeding of clouds. ${ }^{47}$ Cloud seeding is a climate technique designed to increase or release the water in clouds in circumstances in which it would not naturally fall on its own. ${ }^{48}$ Precipitation enhancement usually involves the injection of a seeding substance, such as dry ice, which is $\mathrm{CO}_{2}$ in solid form, or silver iodide. ${ }^{49}$

The covert program began in 1966 with the aim of slowing the delivery of supplies and troop movements in Vietnam by extending the monsoon season. ${ }^{50}$ From 1967 to 1972 the U.S. Air Force flew more than 2600 cloud-seeding sorties over Cambodia, Laos and North and South Vietnam. ${ }^{51}$ The practice was eventually revealed to the public in 1971 , to widespread outrage, while the following scandal became known as the "Watergate of weather warfare." 52

In July of 1972 the U.S. renounced the use of climate modification techniques for hostile purposes with the U.S. Senate calling for an international agreement prohibiting the use of

\footnotetext{
${ }^{47}$ Virginia Simms "Making the Rain: Cloud Seeding, the Imminent Freshwater Crisis, and International Law" (2010) 44 Int'l Law 915 at 935.

${ }^{48}$ At 918.

${ }^{49}$ Xueliang Guo and Guoguang Zheng and Dezhen Jin "A Numerical Comparison Study of Cloud Seeding by Silver Iodide and Liquid Carbon Dioxide" (2006) 79 Atmospheric Research 183 at 183 - 184.

${ }^{50}$ Simms, above $\mathrm{n} 47$, at 935 .

${ }^{51}$ Ty McCormick “Anthropology of an Idea: Geoengineering” (2013) 202 Foreign Policy 28 at 28.

${ }^{52}$ At 28 .
} 
any environmental or geophysical modification activity as a weapon on war. ${ }^{53}$ The ensuing discussions with the Soviet Union culminated in the creation of the Convention on the Prohibition of Military or Any Other Hostile Use of Environmental Modification Techniques (ENMOD). ${ }^{54}$ ENMOD itself is clearly aimed at proscribing conduct by establishing limits on the use of the environment as a type of weapon or an instrument of military operations. ${ }^{55}$ The substantive provisions of the Convention make this explicit, with Article 1 stating that each State Party: ${ }^{56}$

...undertakes not to engage in military or any other hostile use of environmental modification techniques having widespread, long-lasting or severe effects as the means of destruction, damage or injury to any other State Party.

Article 2 gives the definition of the critical term whereby "environmental modification techniques":.57

...refers to any technique for changing - through the deliberate manipulation of natural processes - the dynamics, composition or structure of the Earth, including its biota, lithosphere, hydrosphere and atmosphere, or outer space.

Although specifically dealing with environmental modification, ENMOD is not an instrument that is relevant to geoengineering governance with respect to climate change mitigation efforts. ENMOD, in its preamble, does recognise that "scientific and technical

\footnotetext{
${ }^{53}$ United Nations Office at Geneva "Convention in the Prohibition of Military or Any Other Hostile Use of Environmental Modification Techniques (ENMOD) <http://www.unog.ch/enmod $>$.

${ }^{54}$ Convention on the Prohibition of Military or Any Other Hostile Use of Environmental Modification Techniques 1108 UNTS 151 (opened for signature 18 May 1977, entered into force 5 October 1978). [ENMOD].

${ }^{55}$ Rex J. Zedalis "Climate Change and the National Academy of Sciences' Idea of Geoengineering: One American Academic's Perspective on First Considering the Text of Existing International Agreements" (2010) European Energy and Environmental Law Review 18 at 19.

${ }^{56}$ ENMOD, art 1.

${ }^{57}$ ENMOD, art 2.
} 
advances may open new possibilities with respect to modification of the environment" and that: ${ }^{58}$

...the use of environmental modification techniques for peaceful purposes could improve the interrelationship of man and nature and contribute to the preservation and improvement of the environment for the benefit of present and future generations...

This language makes it clear that the drafters of the Convention turned their minds to the potential, peaceful benefits of geoengineering. The instrument is not entirely silent on nonmilitary uses. It clearly contemplates peaceful uses that could benefit humankind but also implicitly recognises that non-military purposes may also create their own problems. The point is reiterated by the language of Article 3(1) which states that: ${ }^{59}$

The provisions of this Convention shall not hinder the use of environmental modification techniques for peaceful purposes and shall be without prejudice to the generally recognized principles and applicable rules of international law concerning such use.

Thus the language of the Convention makes it clear that there is nothing in the instrument that should be seen as exerting force on non-hostile environmental modification. On this interpretation and from the perspective of geoengineering, there is nothing in ENMOD that expresses a position on the use of peaceful geoengineering for the purposes of climate change mitigation, whether in connection with the sea or not.

\section{Carbon Dioxide Removal}

The Royal Society provides a useful, fairly comprehensive definition of geoengineering, for the purposes of this paper, describing it as "the deliberate large-scale intervention in the earth's climate system, in order to moderate global warming" $" 60$ and divides geoengineering

\footnotetext{
${ }^{58}$ ENMOD, preamble.

${ }^{59}$ ENMOD, art 3(1).

${ }^{60}$ Royal Society, above n 13, at ix.
} 
methods into two basic categories. This definition and categorisation omits some geoengineering techniques, but they are beyond the scope of this paper.

The first technique is called Carbon Dioxide Removal (CDR) and concerns itself with the removal of $\mathrm{CO}_{2}$ from the atmosphere. ${ }^{61}$ Some of the main $\mathrm{CDR}$ methods include: ${ }^{62}$

- Land use management to protect or enhance land carbon sinks;

- The use of biomass for carbon sequestration as well as a carbon neutral energy source;

- Enhancement of natural weathering processes to remove $\mathrm{CO}_{2}$ from the atmosphere;

- Direct engineered capture of $\mathrm{CO}_{2}$ from ambient air;

- The enhancement of oceanic uptake of $\mathrm{CO}_{2}$, for example by fertilisation of the oceans with naturally scarce nutrients, or by increasing upwelling processes.

Ocean iron fertilisation is a CDR technique and is the main focus of this paper.

\section{Solar Radiation Management}

The second broad category of techniques is called Solar Radiation Management (SRM). ${ }^{63}$ These techniques aim to increase the albedo effect of the earth by reflecting a greater proportion of the Sun's irradiance back into space. Some of the main SRM methods include: ${ }^{64}$

- Increasing the surface reflectivity of the planet by brightening human structures, planting of crops with high reflectivity, or covering deserts with reflective material;

- Enhancement of marine cloud reflectivity;

\footnotetext{
${ }^{61}$ At ix.

${ }^{62}$ At ix.

${ }^{63}$ At ix.

${ }^{64}$ At $\mathrm{X}$.
} 
- Mimicking the effects of volcanic eruptions by injecting sulphate aerosols into the lower stratosphere;

- Placing shields or deflectors in space to reduce the amount of solar energy reaching the Earth.

Both SRM and CDR techniques aim to mitigate climate change by reducing surface temperatures.

\section{Ocean Iron Fertilisation}

Ocean iron fertilisation is a subset of fertilisation techniques, all of which share the same broad aim, that is, the removal of carbon dioxide from the atmosphere. The process involves the introduction of micro nutrients to increase phytoplankton productivity in HNLC areas of the ocean. Phytoplankton absorb $\mathrm{CO}_{2}$ as part of the photosynthesis process. ${ }^{65}$ The phytoplankton eventually die and fall to the bottom of the ocean thereby transporting the carbon from the atmosphere and depositing it on the ocean floor for a number of years. The introduction of iron is designed to stimulate this process

\section{The Potential Benefits of Ocean Iron Fertilisation}

Phytoplankton that fulfil this role are participants in a process referred to as a "biological carbon pump". ${ }^{66}$ The organisms not only transport the carbon to the depths, they may enter the food chain by being consumed by other zooplankton. This can in turn lead to an increase in species such as krill and other organisms further up the food chain. Bacteria may also

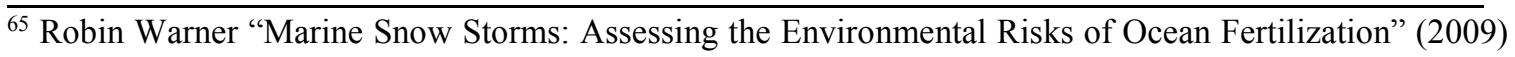
4 CCLR 426 at 427.

${ }^{66}$ James Edward Peterson "Can Algae Save Civilization? A Look at Technology, Law, and Policy Regarding Iron Fertilization of the Ocean to Counteract the Greenhouse Effect" (1995) 6 Colo. J. Int'l Envtl. L. \& Pol'y 61 at 69.
} 
assist in the breakdown of phytoplankton and may increase the transport of carbon to deeper water through fecal pellets. ${ }^{67}$

Clearly the major benefit of ocean iron fertilisation is the mitigation of climate change. However in a world of finite resources, the cost of doing so is highly relevant. Early costs for iron fertilisation estimate the value to be around $\$ 1$ billion to transfer two billion tonnes of atmospheric carbon to the deep ocean. ${ }^{68}$ Other models factor in a portfolio of geoengineering options which calculate that the net present value of a geoengineering programme extended into perpetuity is of the order of $\$ 100$ billion dollars. ${ }^{69}$ This pales in significance to the estimated cost of future mitigation at $\$ 1$ trillion. ${ }^{70}$ Other scholars refer to the economics of geoengineering as "incredible" and estimate that the cost of off-setting the warming effect of rising greenhouse gas concentrations could cost only $\$ 1$ billion per year by the year $2100 .^{71}$ The economic benefits appear to be congruous with the overall health and ecosystem benefits.

\section{The Potential Harms of Ocean Iron Fertilisation}

There are a number of significant concerns associated with ocean iron fertilisation, indeed manipulation of the environment can produce a visceral reaction in many people. General concerns focus on the alteration of the ocean chemistry that is the foundation of important biological cycles and ecosystems. ${ }^{72}$ Research has also shown that iron fertilisation can lead

\footnotetext{
${ }^{67}$ At 71.

${ }^{68}$ At 76.

${ }^{69}$ David G. Victor “On the Regulation of Geoengineering” (2008) 24 Oxford Review of Economic Policy 322 at 326.

${ }^{70}$ At 326.

${ }^{71}$ Scott Barrett “The Incredible Economics of Geoengineering” (2008) 39 Environ Resource Econ 45 at 49.

72 Duncan E.J. Currie and Keteryna Wowk "Climate Change and $\mathrm{CO}_{2}$ in the Oceans and Global Oceans Governance (2009) 4 CCLR 387 at 394.
} 
to an increased acidification of the ocean at deeper depths. ${ }^{73}$ This too may have an impact on delicate ecosystems.

Economic incentives created by ocean iron fertilisation may exacerbate the potential harms. As discussed further on this paper, various market actors seem to be motivated not out of altruism, but more in the search of easy profits. Successful $\mathrm{CO}_{2}$ sequestration activities may earn significant carbon credits which firms can use to offset their own carbon emissions. It is this type of incentive that has been the driver of 'rogue' ocean iron fertilisation around the world.

\section{Social and Ethical Implications and the Moral Hazard of Geoengineering}

Humans have been intentionally manipulating the environment on a scale for years and unintentionally on a large scale in recent times. Anthropogenic interference in the global climate is the precise problem that geoengineering attempts to solve. ${ }^{74}$ The intentionality element of large scale geoengineering is what separates it from previous anthropogenic interference, and this asymmetry between intended and unintended acts, is clearly observed in other areas of the law. ${ }^{75}$ Geoengineering may be seen as attacking the symptoms rather than the source of the problem. It may deflect from the real problem and do nothing to challenge the systems of production and consumption that may be considered unsustainable. ${ }^{76}$ Ignoring the social cause of climate change may contribute to a willingness to use possibly dangerous mitigation techniques. This is the main problem, the trade-off between the potential for disastrous consequences from geoengineering, and the potential for disastrous consequences through inaction.

\footnotetext{
${ }^{73}$ Warner, above $\mathrm{n} 65$, at 427.

${ }^{74}$ Adam Corner and Nick Pidgeon "Geoengineering the Climate: The Social and Ethical Implications" (2010) 52 Environment 25 at 28.

${ }^{75}$ At 28.

${ }^{76}$ At 31 .
} 
The problem may be encapsulated by the moral hazard concept. A moral hazard is the tendency for actors to take fewer precaution when they know they are insured. ${ }^{77}$ Insured, in a climate change sense, refers to the mitigation of increased temperatures through geoengineering deployment. These endeavours are likely to undermine efforts to mitigate climate change, thus geoengineering presents a strong economic, political and psychological temptation to defer difficult actions to future generations. ${ }^{78}$ This moral hazard is a concern, especially to those who regard geoengineering practices such as ocean iron fertilisation, as being inferior, problematic and temporary options. ${ }^{79}$

\section{The Law of the Sea and Ocean Iron Fertilisation - the Current Regulatory Regime, Evolution and Analysis}

This part looks at the legal instruments and principles relevant to the practice of geoengineering, with a particular emphasis on the law of the sea and ocean iron fertilisation. It critically analyses the issue of dumping to examine whether ocean iron fertilisation activities are able to be brought within the exception to the definitions of dumping, thereby exempting such conduct from the purview of the relevant instruments. Additionally, it examines the effectiveness and appropriateness of the law at proscribing ocean iron fertilisation.

\section{A UNCLOS}

The 1982 United Nations Convention on the Law of the Sea ("UNCLOS") has been described as a constitution for the oceans, and the importance of this instrument on the international plane was reflected in the record number of 119 countries who signed it, on

\footnotetext{
${ }^{77}$ Robert H. Frank and Ben S. Bernanke Principles of Economics (2nd ed, McGraw-Hill/Irwin, New York, 2004) at 316.

${ }^{78}$ Albert C. Lin “Does Geoengineering Present a Moral Hazard?” (2013) 40 Ecology LQ 673 at 711.

${ }^{79}$ At 711.
} 
the very first day on which it was opened for signature. ${ }^{80}$ Although participants in the negotiations undoubtedly expected the emergence of new ocean uses in the future, they are unlikely to have held ocean iron fertilisation and other geoengineering techniques amongst them.

The provisions of the Convention provide the legal framework which informs and proscribes State behaviour with respect to conduct at sea. The Convention's 320 Articles and nine Annexes were drafted to cover marine issues comprehensively. ${ }^{81}$ The international law of the sea is bookended by two contrary principles of international law, the principle of freedom and the principle of sovereignty. ${ }^{82}$ The former aims to ensure the freedom of use of activities such as fishing and marine scientific research while the latter promotes the extension of national jurisdiction into offshore areas and supports the territorialisation of the seas. ${ }^{83}$ The Law of the Sea Convention is given the task of balancing the many competing rights and interests that arise out of State conduct involving the oceans.

UNCLOS recognises in its preamble: ${ }^{84}$

...the desirability of establishing through this Convention, with due regard for the sovereignty of all States, a legal order for the seas and oceans which will facilitate international communication, and will promote the peaceful uses of the seas and oceans, the equitable and efficient utilization of their resources, the conservation of their living resources, and the study, protection and preservation of the marine environment...

Furthermore it also reasserts that areas beyond the limits of national jurisdiction are the common heritage of mankind. ${ }^{85}$

\footnotetext{
${ }^{80}$ Tommy T.B. Koh, President of the Third United Nations Conference on the Law of the Sea "A Constitution for the Oceans" (6 and 11 December 1982) Oceans and Law of the Sea <www.un.org>.

${ }^{81}$ Yoshifumi Tanaka The International Law of the Sea (Cambridge University Press, New York, 2012) at 31.

${ }^{82}$ At 16.

${ }^{83}$ At $16-17$.

${ }^{84}$ UNCLOS, preamble.

${ }^{85}$ UNCLOS, preamble.
} 
Part XII of UNCLOS is concerned with the protection and preservation of the marine environment. Article 192 provides States with a general obligation providing that "States have the obligation to protect and preserve the marine environment". ${ }^{86}$ This provision must be read in light of Article 193 which qualifies it to some extent, providing that "States have the sovereign right to exploit their natural resources pursuant to their environmental policies and in accordance with their duty to protect and preserve the marine environment." 87

Article 194 provides for measures to prevent, reduce and control pollution of the marine environment, both in general and under specific State jurisdiction: ${ }^{88}$

1. States shall take, individually or jointly as appropriate, all measure consistent with this Convention that are necessary to prevent, reduce and control pollution of the marine environment from any source, using for this purpose the best practicable means at their disposal and in accordance with their capabilities, and they shall endeavour to harmonize their policies in this connection.

2. States shall take all measures necessary to ensure that activities under their jurisdiction or control are so conducted as not to cause damage by pollution to other States and their environment, and that pollution arising from incidents or activities under their jurisdiction or control does not spread beyond the areas where they exercise sovereign rights in accordance with this Convention.

Article 194(1) is of considerable width, it imposes State obligations with regard to pollution from any source. Article 194(2) impliedly reinforces and acknowledges that areas beyond the limits of national jurisdiction are the common heritage of mankind by ensuring that pollution does not spread beyond areas where sovereign rights may be exercised, whilst also respecting the principles of sovereignty and freedom.

\footnotetext{
${ }^{86}$ UNCLOS, art 192.

${ }^{87}$ Article 193.

${ }^{88}$ Article 194.
} 
The definition of "pollution of the marine environment" is found in Article 1(4) which states: ${ }^{89}$

(4) "pollution of the marine environment" means the introduction by man, directly or indirectly, of substances or energy into the marine environment, including estuaries, which results or is likely to result in such deleterious effects as harm to living resources and marine life, hazards to human health, hindrance of marine activities, including fishing and other legitimate uses of the sea, impairment of quality for use of sea water and reduction of amenities;

This definition focuses not on the nature of the substance per se, but rather the potential deleterious effects that the introduction of the substance may have. ${ }^{90}$ Proponents of ocean iron fertilisation may contend that their activities do not fall within this definition of pollution as those activities do not result nor are likely to result in the deleterious effects proscribed..$^{91}$ One reason for this is that the dire results of ocean iron fertilisation, advanced by some, are predicated on worst-case scenarios. ${ }^{92}$ Moreover, ocean iron fertilisation may be beneficial to the ecosystem, particularly in areas such as the Southern Ocean, where Antarctic krill forms the food base of Antarctic fauna such as whales, seals and penguins. ${ }^{93}$ Scientists have postulated that the ongoing krill decline, which is placing the recovery of whale populations in serious jeopardy, may be reverse by larger scale ocean iron fertilisation. ${ }^{94}$

There is no consensus on whether the introduction of iron qualifies as pollution. The Royal Society, in its 2009 report, noted that the possible consequences of changing the marine

\footnotetext{
${ }^{89}$ Article 1(4).

${ }^{90}$ David Freestone and Rosemary Rayfuse "Ocean Iron Fertilization and International Law" (2008) 364 Mar Ecol Prog Ser 227 at 229.

${ }^{91}$ Randall S. Abate and Andrew B. Greenlee "Sowing Seeds Uncertain: Ocean Iron Fertilization, Climate Change, and the International Environmental Law Framework" (2010) 27 Pace Envtl. L. Rev. 555 at 574.

${ }^{92}$ V. Smetacek and S. W. A. Naqvi "The Next Generation of Iron Fertilization Experiments in the Southern Ocean” (2008) 366 Phil. Trans. R. Soc. A. 3947 at 3954.

${ }^{93}$ At 3961.

${ }^{94}$ At 3961.
} 
ecosystem were uncertain due to the complexity of the typical ocean food webs but that there "are likely to be unintended and probably deleterious ecological consequences." 95 Furthermore, advocates of ocean iron fertilisation, pointing to the fact that the same iron uptake process occurs naturally ${ }^{96}$, may argue that their activities do not fall within this definition. This argument gains more force particularly when amalgamated with the proposition associated with krill decline. Whether the introduction of iron can be regarded as pollution may be reduced to a question of scientific viewpoint, which itself is inevitably a function of politics.

Article 210 governs pollution by dumping, requiring that: ${ }^{97}$

1. States shall adopt laws and regulations to prevent, reduce and control pollution of the marine environment by dumping.

2. States shall take other measures as may be necessary to prevent, reduce and control such pollution.

4. States, acting especially through competent international organizations or diplomatic conference, shall endeavour to establish global and regional rules, standards and recommended practices and procedures to prevent, reduce and control pollution. Such rules, standards and recommended practices and procedures shall be re-examined from time to time as necessary.

...

6. National laws, regulations and measures shall be no less effective in preventing, reducing and controlling such pollution than the global rules and standards.

Article 1 defines dumping as: ${ }^{98}$

(5) (a) "dumping" means:

(i) any deliberate disposal of wastes or other matter from vessels, aircraft, platforms or other man-made structures at sea;

\footnotetext{
95 The Royal Society, above n 13, at $17-19$.

${ }^{96}$ Lenton and Vaughan, above n 6, at 753.

${ }^{97}$ UNCLOS, art 210.

${ }^{98}$ Article 1(5).
} 
(b) "dumping" does not include:

(ii) placement of matter for a purpose other than the mere disposal thereof provided that such placement is not contrary to the aims of this Convention.

The first part of the definition may appear to capture the introduction of iron as it is open to consider the iron not as waste but rather as falling within the scope of "any other matter". The term "waste" is not defined in UNCLOS yet an exercise in statutory interpretation would conclude that the use of the disjunctive 'or' places separate meanings on 'wastes' and 'other matter'. In any event, iron would appear to be captured by this provision. It could be argued that the term "disposal" is inapplicable to the practice of ocean iron fertilisation as the iron is not being disposed of, rather, it is being introduced for other purposes. However the real purpose of iron introduction is to produce a phytoplankton bloom so as to sequester into the oceans a higher percentage of atmospheric carbon dioxide than would otherwise occur naturally. ${ }^{99}$ The purpose then of ocean iron fertilisation is the "deliberate placement into the oceans of excess atmospheric $\mathrm{CO}_{2}$ for the purpose of disposing of that $\mathrm{CO}_{2} .{ }^{" 100}$ However it is arguable, in countering the above proposition, that the second, exclusionary limb of the definition, may allow for the introduction of iron as its placement is for purposes other than mere disposal. These purposes may be argued to include ocean iron fertilisation conduct and other geoengineering techniques.

The lack of definitional elements around terms such as "waste", "other matter" or "disposal" need not be fatal to the Convention's ability to regulate ocean iron fertilisation activities. As shown in Article 210, parties to UNCLOS are obliged to adopt national laws, regulations and other measures to prevent, reduce and control marine pollution by dumping, which are no less effective than the global rules and standards. The relevant global rules and standards are universally considered to be those adopted under the other

\footnotetext{
$\overline{{ }^{99} \text { Rosemary Rayfuse "Drowning Our Sorrows to Secure a Carbon Free Future? Some International Legal }}$ Considerations Relating to Sequestering Carbon by Fertilising the Oceans" (2008) 31 UNSW LJ 919 at 924. ${ }^{100}$ At 924.
} 
instruments to be considered, ${ }^{101}$ namely the London Convention. ${ }^{102}$ Article 210(4) also requires States to revisit and re-examine the rules and standards from time to time, therefore it follows that the adoption of future protocols, for example the 1996 London Protocol, could be regarded as a fulfilment of States' revision obligations under the Article. ${ }^{103}$ Hence the provisions of other relevant instruments and protocols are imported into UNCLOS and must be implemented by States who are party to UNCLOS but not the other instruments. Some scholars have considered that not only does UNCLOS delegate the promulgation of global rules and standards to other treaties, it also endorses the recently enacted rules and standards developed under the Convention of Biological Diversity ${ }^{104}$ (CBD) and the London Protocol which specifically address the issue of ocean iron fertilisation on the high seas. ${ }^{105}$

The above articles are indicative of the broad framework nature of UNCLOS, with Contracting Parties being left to flesh out details in other instruments or at the domestic level. While UNCLOS may exert general pressure on States wishing to pursue ocean fertilisation techniques, it does not provide any specific, substantive guidance on the subject. Rather, this is left to the other relevant international instruments which will be considered next.

B The 1972 Convention on the Prevention of Marine Pollution by Dumping of Wastes and Other Matter and the 1996 Protocol to the 1972 Convention on the Prevention of Marine Pollution by Dumping of Wastes and Other Matter

\footnotetext{
${ }^{101}$ Louise de La Fayette "The London Convention 1972: Preparing for the Future" (1998) 13 Int'1 J. Marine \& Coastal L. 515 at 516.

${ }^{102}$ London Convention.

${ }^{103}$ de La Fayette, above n 100, at 516.

1041992 Convention on Biological Diversity 1760 UNTS 79 (opened for signature 5 June 1992, entered into force 29 December 1993).

${ }^{105}$ Abate and Greenlee, "Sowing Seeds Uncertain", above n 91, at $575-576$.
} 
The 1972 Convention on the Prevention of Marine Pollution by Dumping of Wastes and Other Matter106 ("London Convention"/"The Convention") and the 1996 Protocol to the 1972 Convention on the Prevention of Marine Pollution by Dumping of Wastes and Other Matter 107 ("London Protocol"/"The Protocol") both contain provisions which attempt to regulate and control the deliberate dumping of substances at sea. The London Protocol was developed with the intention of replacing the London Convention yet there remain States that are signatories of the former only and so the two instruments coexist in parallel.

The legal relationship between the two is not obvious. ${ }^{108}$ The London Protocol is a modern version of the London Convention and is not qualified to be an executive regulation of the Convention. ${ }^{109}$ Article 23 of the Protocol clarifies the relationship between the two, stating that the "Protocol will supersede the Convention as between Contracting Parties to the Protocol which are also Parties to the Convention." 110

Both the London Convention and the London Protocol contain provisions that require Contracting Parties to protect and preserve the marine environment from all sources of pollution and where practicable, to eliminate pollution caused by the dumping of wastes or other matter. Article 1 of the Convention states that: ${ }^{111}$

Contracting Parties shall individually and collectively promote the effective control of all sources of pollution of the marine environment, and pledge themselves especially to take all practicable steps to prevent the pollution of the sea by the dumping of waste and other matter that is liable to create hazards to human health, to harm living resources and marine life, to damage amenities or to interfere with legitimate uses of the sea.

\footnotetext{
${ }^{106}$ London Convention.

${ }^{107}$ London Protocol.

108 Dr. Harald Ginzky “Ocean Fertilization as Climate Change Mitigation Measure - Consideration under International Law" (2010) 7 J. Eur. Envtl. \& Plan. L. 57 at 63.

109 At 63.

${ }^{110}$ London Protocol, art 23.

${ }^{111}$ London Convention, art 1.
} 
Article 2 of the Protocol, which extends the wording of the respective Article 2 of the Convention, provides that: ${ }^{112}$

Contracting Parties shall individually and collectively protect and preserve the marine environment from all sources of pollution and take effective measures, according to their scientific, technical and economic capabilities, to prevent, reduce and where practicable eliminate pollution caused by dumping or incineration at sea of wastes or other matter. Where appropriate, they shall harmonize their policies in this regard.

Dumping is defined in the Convention and the Protocol as being: ${ }^{113}$

(a) "Dumping" means:

(i) any deliberate disposal at sea of wastes or other matter from vessels, aircraft, platforms or other man-made structures at sea; $\cdots$

(b) "Dumping does not include:

(ii) placement of matter for a purpose other than the mere disposal thereof, provided that such placement is not contrary to the aims of this Convention.

A similar analysis to the definition of dumping under UNCLOS may be applied. The first part of the definition would appear to encompass the introduction of iron as it can be considered other matter and this matter is undoubtedly being introduced into the ocean. ${ }^{114}$ However it can be argued that the matter is not being disposed of, rather it is being introduced for a specific purpose that being, the removal of carbon dioxide from the atmosphere. This line of reasoning has been outlined by Scott although no final opinion is expressed on the point. ${ }^{115}$ Ginzky follows a similar line of reasoning but turns to the

\footnotetext{
${ }_{112}$ London Protocol, art 2.

${ }^{113}$ London Convention, art 3; London Protocol, art 1.

${ }^{114}$ Karen N. Scott "Regulating Ocean Fertilization under International Law: The Risks" (2013) 2 CCLR 108 at 112 .

${ }^{115}$ At 112 .
} 
exemption clause, stating that the term "dumping" does not comprise the input of substances if those input substances pursue another purpose other than the mere disposal. ${ }^{116}$ On this footing, the exemption clause is only applicable if the matter introduced is not contrary to the aims of the Convention or Protocol, a condition which is readily distilled from the language used in each instrument.

If this interpretation is accepted, it would seem to open the door to iron fertilisation. If the placement can be characterised as being for a purpose other than the mere disposal thereof, that is, for the mitigation of climate change through carbon sequestration, it would fall outside the definition of dumping and the regulatory regime. It is this exception that is being relied upon at present to permit ocean iron fertilisation for legitimate scientific purposes. ${ }^{117}$ The performance of large-scale ocean iron fertilisation for climate change mitigation purposes could be characterised as "placement of matter for a purpose other than the mere disposal thereof" in which case it would be excluded from the definition of dumping and, accordingly, the controls on dumping under the Convention and Protocol. ${ }^{118}$

However the introduction of iron must still be compatible with the aims of the Convention or Protocol. The aims of the instruments can be extracted as being the prevention of pollution and dumping that creates human health hazards or that harms marine life and living resources. ${ }^{119}$ Research has indicated that a wide range of undesirable side effects may be associated with iron fertilisation. ${ }^{120}$ Some effects relate to the disruption of marine food webs which could have disastrous flow on effects for other organisms and species, and more disturbingly may actually result in the warming of the atmosphere and ocean surface. ${ }^{121}$ It is at least tenable that iron fertilisation is in opposition to the aims of the London Convention and the London Protocol. Scientific viewpoints will once again be

\footnotetext{
${ }^{116}$ Ginzky, above n 108, at 64 .

${ }^{117}$ Scott "Regulating Ocean Fertilization under International Law: The Risks", above n 114, at 112.

118 At 112 .

${ }^{119}$ London Convention, art 1; London Protocol, art 1.

${ }^{120}$ Freestone and Rayfuse, above n 90, at 229.

121 At 230.
} 
brought to bear on the question, with research judiciously selected to support opposing positions. It is clear however, that insofar as ocean iron fertilisation potentially or actually causes significant marine pollution, it should be declared incompatible with the aims of the Convention and Protocol and therefore excluded from the 'other purpose' exemption. ${ }^{122}$

An analysis may also proceed that is independent of the purpose for which the matter was introduced. Recalling the definition of "dumping" as meaning "any deliberate disposal of wastes or other matter from vessels", ${ }^{123}$ ocean fertilisation ostensibly involves the deposition of iron into the ocean from vessels. ${ }^{124}$ Whilst neither the Convention nor the Protocol define 'disposal', its ordinary meaning indicates deposition for the purpose of abandonment, that is, iron deposited during fertilisation is abandoned with no intention of recovery. ${ }^{125}$ This leads to the conclusion that it has effectively been disposed of and therefore such conduct cannot take advantage of the 'other purpose' exemption. Article 31 of the Vienna Convention on the Law of Treaties states that a "treaty shall be interpreted in good faith in accordance with the ordinary meaning to be given to the terms of the treaty in their context and in the light of its object and purpose." ${ }^{126}$ Interpreting 'disposal' as meaning abandonment with no intention of recovery, is not inconsistent with the Article 31(1) general rule of interpretation.

Freestone and Rayfuse develop an argument that bypasses the question of compatibility with the aims of the Convention and the Protocol. ${ }^{127}$ They re-examine the purpose of the ocean fertilisation and conclude that it is to "draw down carbon dioxide from the

\footnotetext{
122 Scott at 112.

${ }^{123}$ London Convention, art 3; London Protocol, art 1.

${ }^{124}$ Rosemary Rayfuse and Mark G. Lawrence and Kristina M. Gjerde "Ocean Fertilisation and Climate Change: The Need to Regulate Emerging High Seas Uses” (2008) 23 Int'l J. Marine \& Coastal L. 297 at 312. 125 At 312 .

126 Vienna Convention on the Law of Treaties 1155 UNTS 331 (opened for signature 23 May 1969, entered into force 27 January 1980), art 31(1).

${ }^{127}$ Freestone and Rayfuse, above n 90, at 229.
} 
atmosphere for storage in the ocean."128 They conclude that ocean fertilisation is the indirect placement of carbon dioxide for the purpose of disposal. ${ }^{129}$ This analysis relies on the element of causality between the introduction of the iron and the sequestration of the carbon dioxide such that the end result constitutes dumping, thereby bringing the activity within the scope of the both the Convention and the Protocol. Although a valid argument, and certainly an interesting approach to the issue, it is difficult to see it gaining much currency. Opponents are likely to latch on to the causality aspect, citing an inherent weakness in the argument, inevitably claiming that the link is too tenuous. Additionally, it is arguable that the carbon dioxide is not being disposed of but merely stored in the medium term, to be released once again through natural processes. Adopting this viewpoint may allow the activity to fall outside of the scope of the Convention and the Protocol, or at the least, to rebut the indirect placement argument.

Both the London Convention and the London Protocol contain provisions permitting the dumping of matter at sea. Article 4 of the Convention requires a Contracting Party to prohibit the dumping of wastes, the relevant provisions being as follows: ${ }^{130}$

1. In accordance with the provisions of this Convention Contracting Parties shall prohibit the dumping of any wastes or other matter in whatever form or condition except as otherwise specified below:

(a) the dumping of wastes or other matter listed in Annex I is prohibited;

(b) the dumping of wastes or other matter listed in Annex II requires a special permit;

(c) the dumping of all other wastes or matter requires a prior general permit.

However nothing in the "Convention is to be interpreted as preventing a Contracting Party from prohibiting, insofar as that Party is concerned, the dumping of wastes or other matter

\footnotetext{
128 At 229.

${ }^{129}$ At 229.

${ }^{130}$ London Convention, art 4; Annex $1-2$.
} 
not mentioned in Annex 1."131 Therefore member States are able to apply a narrow interpretation and application of the Convention if they wish. Iron is not listed in either Annex and is prima facie not covered by the Convention. The Protocol has a reverse approach to dumping, prohibiting all waste and other matter, with the exception of those listed in Annex 1, which may be considered for dumping, with a permit, while being mindful of the objectives and obligations set out in the protocol. ${ }^{132}$

The closest applicable substance relates to scrap metal. Annex 2B of the Convention proscribes "Containers, scrap metal and other bulky wastes liable to sink to the sea bottom which may present a serious obstacle to fishing or navigation." 133 The Protocol has a more extensive definition but similarly lists, amongst other things, "bulky items primarily comprising iron". ${ }^{134}$ However the introduction of iron is usually in the form of iron phosphate or iron filings and therefore would not be characterised as scrap metal. This precludes the granting of a special permit for the type of iron used in ocean iron fertilisation. However Annex I of the Convention may allow for the specially permitted dumping of iron under the auspices of industrial waste, the definition of which is: ${ }^{135}$

"Industrial waste" means waste materials generated by manufacturing or processing operations and does not apply to:

(e) uncontaminated inert geological materials the chemical constituents of which are unlikely to be released into the marine environment;

The Protocol contains a similar definition, expanding it with the addition of "inorganic", to allow the dumping, by special permit, of "inert, inorganic geological material". ${ }^{136}$ Iron satisfies admission to the class of materials that are geological, and due to the absence of

\footnotetext{
${ }^{131}$ London Convention, art 4.

${ }^{132}$ London Protocol, art 4.

${ }^{133}$ London Convention Annex 2B.

${ }^{134}$ London Protocol Annex 1.1.7.

135 London Convention Annex 2.11

${ }^{136}$ London Protocol Annex 1.1.5.
} 
the carbon atoms and chains found in organic chemistry, is certainly defined as being inorganic. Thus the key question of whether iron may be covered by this exclusion, and therefore open to being permitted under the Annex, is the definition of "inert". ${ }^{137}$ Rayfuse et al, state that the iron being introduced into the ocean for iron fertilisation purposes must be in a biologically available form so that it can be taken up and used by the phytoplankton. ${ }^{138}$ They conclude that it is difficult to argue that this iron can be classified as an inert material, and therefore the prohibition is complete. ${ }^{139}$ Their conclusion may be in accord with those of other scholars, however a more thorough analysis has been undertaken by Scott.

The Convention Guidelines require that materials that are classified as inert must be essentially chemically unreactive. ${ }^{140}$ There is no general scientific consensus as to what the definition of inert is, some chemists take a strict approach that requires no possibility of a chemical reaction, while others assess inertness in a relative sense by focusing on the toxicity of the compound or substance. ${ }^{141}$ This latter definition appears to be supported by the literature, which states that: ${ }^{142}$

...key factors in determining if a proposed material is inert are knowledge of the material's constituents, including any potential contaminants, and what, if any, reactions might occur following the material's exposure to physical, chemical, or biological processes in the marine environment. Material that may result in acute or chronic toxicity, or in bioaccumulation of any of its constituents, should not be considered inert.

Iron is inherently toxic and its introduction to the marine environment in this context is to deliberately create a reaction, the phytoplankton bloom, and therefore under these

\footnotetext{
${ }^{137}$ Scott "Regulating Ocean Fertilization under International Law: The Risks", above n 114, at 113.

${ }^{138}$ Rayfuse and others, above n 124 , at 312.

${ }^{139}$ At 312.

${ }^{140}$ Karen Scott "International Law in the Anthropocene: Responding to the Geoengineering Challenge" (2013) 34 Michigan Journal of International Law 309 at 338.

141 At 338.

${ }^{142}$ Scott "Regulating Ocean Fertilization under International Law: The Risks", above n 114, at 113.
} 
conditions it is highly unlikely that it would be considered as an inert substance. ${ }^{143}$ It follows that the dumping of iron for the purposes of climate change mitigation through ocean iron fertilisation, would not be an activity for which a permit could be granted under either the London Convention or the London Protocol by virtue of its inertness.

The preceding analysis converges to the central issue of ocean iron fertilisation under the Convention and the Protocol. That is "whether it is exempt from the ban on dumping by virtue of the operation of the exception to the definition of dumping found...in the London Convention and the London Protocol." "144 Unless the introduction of iron into the marine environment for climate change mitigation purposes can be categorised as placement for purposes other than disposal, then that introduction would appear to be prohibited by, and in violation of the London Protocol. ${ }^{145}$ Similarly for the Convention, ocean fertilisation activities may not be prohibited if they can be categorised as placement for purposes other than disposal. Recalling Article 4, which does the substantive work regarding prohibition, iron is not specifically listed in Annex 1 and so escapes prohibition on those grounds unless it may be considered as inert industrial waste. However the discussion above concluded that this would be unlikely. Annex 2D lists the substances and materials that may be dumped with a special permit which includes "Materials which, though of a non-toxic nature, may become harmful due to the quantities in which they are dumped, or which are liable to seriously reduce amenities. Therefore it is likely that the quantities of iron necessary in a large-scale climate change mitigation project would be such as to render them harmful thereby attracting the requirement of a special permit. ${ }^{146}$ In the case that the introduced iron was of an insufficient quantity, this activity would fall outside the scope of Annex II and qualify for inclusion in the general permit regime.

\footnotetext{
143 At 113.

144 Rayfuse and others, above n 124, at 313.

${ }^{145}$ Scott "Regulating Ocean Fertilization under International Law: The Risks", above n 114, at 113.

${ }^{146}$ At 113.
} 
The next section shall look at the events that led to the introduction of ocean fertilisation practices to the relevant bodies, and examine the responses of States to these practices and the changes to the law that have occurred as a result.

1 The Introduction of Ocean Iron Fertilisation to the Scientific Group and Consultative Meeting of the Parties under the London Convention

Ocean iron fertilisation was first drawn to the attention of the International Maritime Organization's (IMO) Scientific Group under the London Convention, at the $22^{\text {nd }}$ Meeting in May 1999. A paper submitted by Greenpeace International, sought to inform the Scientific Group of matters concerning the ocean disposal and sequestration of carbon dioxide. ${ }^{147}$ Greenpeace expressed numerous concerns. Some of these doubted the efficacy of fertilisation practices and its attendant risks but perhaps the broadest concern was that "the current pace of discussions and developments in the field of ocean disposal of $\mathrm{CO}_{2}$ threatens to overtake consideration of the environmental, legal and ethical implications of such practices." 148

The report of the $22^{\text {nd }}$ Meeting of the Scientific Group did not specifically address ocean fertilisation directly, as a means of carbon dioxide removal but did refer to the Greenpeace submission. ${ }^{149}$ The report acknowledged the concept and rationale underlying $\mathrm{CO}_{2}$ disposal at sea and highlighted concerns surrounding effectiveness and environmental impact. ${ }^{150}$ However the Group chose not to express an opinion on iron fertilisation in spite of the

\footnotetext{
${ }^{147}$ Greenpeace International Ocean Disposal/Sequestration of Carbon Dioxide, Submission to the Scientific Group of the London Convention, 22 ${ }^{\text {nd }}$ Meeting, Agenda Item 11, IMO Doc E/LC/SG 22/INF .20 (19 March 1999).

${ }^{148}$ At 2.

${ }^{149}$ Report of the Twenty-Second Meeting of the Scientific Group, Scientific Group of the London Convention, $22^{\text {nd }}$ Meeting, Agenda Item 13, IMO Doc E/LC/SG 22/13 (10 June 1999) at 11.

${ }^{150}$ At 11 .
} 
explicit examples contained in the Greenpeace report, preferring instead to conclude that: ${ }^{151}$

Within the context of the London Convention 1972, fossil fuel derived $\mathrm{CO}_{2}$ is industrial waste and, as a result, the dumping of such $\mathrm{CO}_{2}$ from ships or platforms at sea or disposal into the sea floor was illegal. As such, the issue required urgent attention by the Consultative Meeting.

The $21^{\text {st }}$ Consultative Meeting of Contracting Parties to the London Convention convened in October 1999. Among the matters for consideration was the issue of ocean disposal and sequestration of $\mathrm{CO}_{2}$ that was brought up at the meeting of the Scientific Group. The Chairman of the Consultative Meeting "noted that there was no consensus on whether or not ocean disposal of $\mathrm{CO}_{2}$ from fossil fuelled power production would be considered an industrial waste" 152 but did not approach the topic of ocean fertilisation. The Chairman concluded that the Scientific Group should continue to monitor the developing research in this field and that the Consultative Meeting "would consider the legal, political and institutional dimensions of a potential proposal to amend the Convention or the 1996 Protocol at a later stage."153

Consideration of these dimensions became necessary in 2007 when the Planktos Corporation, and it's then CEO Russ George, announced plans to conduct iron fertilisation experiments. ${ }^{154}$ The US domiciled company revealed plans to dump around 100 tonnes of iron particulate matter, from the Weatherbird II, A U.S.-flagged vessel, into the Pacific Ocean off the coast of the Galapagos Islands, in order to trigger a phytoplankton bloom.

\footnotetext{
${ }^{151}$ At 11.

${ }^{152}$ Report of the Twenty-First Consultative Meeting, Twenty-First Consultative Meeting of Contracting Parties to the Convention on the Prevention of Marine Pollution by Dumping of Wastes and Other Matter, Agenda Item 13, IMO Doc E/LC 21/13 (1 November 1999) at 17.

${ }^{153}$ At 17.

154 Catherine Brahic "Company Plans 'Eco' Iron Dump off Galapagos" $<$ http://www.newscientist.com/article/dn12111-company-plans-eco-iron-dump-offgalapagos.html\#.VCJ9T_mSxvE >
} 
This dumping was significantly larger than the small-scale scientific experiments that had been conducted up until that date. The $30^{\text {th }}$ Meeting of the Scientific Group of the London Convention was held in June 2007 and directly addressed the proposal. Submissions were received from interested groups including the United States and Greenpeace, conveying concerns about the activities of Planktos. The United States Environmental Protection Agency (EPA) contacted Planktos seeking additional information about its activities. Through its discussions, the EPA discovered that a primary goal of this project was to "assess whether the large-scale iron additions result in carbon sequestration that can be quantified, verified, and sold in the global carbon credit market, particularly in the European Union." 155

The EPA was of the opinion that this project would potentially be subject to the United States' Marine Protection, Research, and Sanctuaries Act (MPRSA or the "Ocean Dumping Act"), the US legislation that implements the London Convention on ocean dumping, due to the involvement of a United States' flagged vessel, and would therefore be required to obtain the requisite permits under the Act. ${ }^{156}$ The response from a Planktos representative was to declare their intention of using a non-U.S. flagged vessel to avoid being subject to U.S. jurisdiction through the Ocean Dumping Act. ${ }^{157}$ The EPA expressed further concerns over the lack of any information relating to an environmental impact assessment by the company or any other regulatory body. The United States invited any State that had appropriate jurisdiction, to evaluate the iron fertilisation projects proposed by Planktos. ${ }^{158}$ Furthermore, and tellingly, the United States saw it fit to note that dumping, under the London Convention, does not include the placement of matter for a purpose other than the mere disposal thereof, provided that it is not contrary to the aims of the Convention. ${ }^{159}$ This

\footnotetext{
${ }^{155}$ United States Planktos, Inc., Large-scale Ocean Iron Addition Projects, Submission to the Scientific Group of the London Convention $30^{\text {th }}$ Meeting, Agenda Item 12, IMO Doc E/LC/SG 30/INF.28 (1 June 2007) at 1.

${ }^{156}$ At 2.

157 At 2.

${ }^{158}$ At 2.

${ }^{159}$ At 2.
} 
statement, although couched in fairly innocuous language, could be viewed as a recognition of the ambiguity present in the law regarding geoengineering techniques such as iron fertilisation.

The Scientific Group recognised that the large-scale fertilisation of the ocean with micronutrients was gaining significant commercial interest. The Group adopted the position that the current state of knowledge regarding the effectiveness of ocean fertilisation and its impact on the environment was "insufficient to justify large-scale operations". ${ }^{160}$ The Group did acknowledge work undertaken by the IPCC which stated that iron fertilisation could become a potential strategy for the removal of atmospheric carbon dioxide, while stressing their conclusion that it firstly remained largely speculative and secondly that the environmental side effects where largely unassessed. ${ }^{161}$ Due to the possible negative impact on the marine environment and indeed upon human health, the Scientific Group recommended that any operations of this nature be evaluated carefully so as not to contravene the aims of the London Convention and Protocol. ${ }^{162}$

\section{The 2007 "Statement of Concern"}

The meeting culminated in the release of a "Statement of Concern" concerning the use of fertilisation techniques to sequester carbon dioxide. The statement echoed concerns showed at the meeting by the Scientific Group and the IPCC regarding environmental impacts and requested action from the next Consultative Meeting of Contracting Parties to

\footnotetext{
${ }^{160}$ Report of the Thirtieth Meeting of the Scientific Group of the London Convention and the First Meeting of the Scientific Group of the London Protocol, Scientific Group of the London Convention $-30^{\text {th }}$ Meeting and Scientific Group of the London Protocol - ${ }^{\text {st }}$ Meeting, Agenda Item 14, IMO Doc E/LC/SG 30/14 (25 July) at 10.

${ }^{161}$ At 10.

${ }^{162}$ At 10 .
} 
the London Convention to "consider the issue of large-scale ocean fertilization operations with a view to ensuring adequate regulation of such operations."163

Three main conclusions were delivered in November 2007, at the $29^{\text {th }}$ Consultative Meeting of the Contracting Parties to the Convention, which would go on to inform further developments in the area of ocean iron fertilisation. Firstly, the Parties endorsed the "Statement of Concern" issued by the Scientific Group. ${ }^{164}$ Secondly, and importantly for legal implications, they agreed that the "scope of the work of the London Convention and Protocol included ocean fertilization, as well as iron fertilization, and that these agreements were competent to address this issue in view of their general objective to protect and preserve the marine environment" ${ }^{165}$ For clarity, the competency of the agreements mentioned here refers to the London Convention and London Protocol. Member States expressed concerns that the global focus should be on reducing $\mathrm{CO}_{2}$ emissions at source instead of pursuing potentially dangerous interim sequestration solutions. ${ }^{166}$ The Meeting reflected these concerns by urging States to use the utmost caution when considering proposals for large-scale ocean fertilization, while also expressing the view that such largescale operations were not currently justified given the present state of knowledge regarding ocean fertilization. ${ }^{167}$ The Legal Intersessional Correspondence Group (LICG) was established and given the task of reporting on the legal issues relevant to ocean fertilisation. The report produced consisted of the results of a questionnaire sent to various Contracting Parties. The questionnaire had invited views on a number of different scenarios. Importantly, Scenario 1 asked Members to consider ocean fertilisation with the addition of

${ }^{163}$ Statement of Concern Regarding Iron Fertilization of the Oceans to Sequester $\mathrm{CO}_{2}$, Scientific Groups of the London Convention and London Protocol, IMO Doc E/LC-LP.1/Circ.14 (13 July 2007) at 2.

${ }^{164}$ Report of the Twenty-Ninth Consultative Meeting and the Second Meeting of Contracting Parties, TwentyNinth Consultative Meeting of Contracting Parties to the London Convention and Second Meeting of Contracting Parties to the London Protocol, Agenda Item 17, IMO Doc E/LC 29/17 (14 December 2007) at 4.

${ }^{165}$ At 4.

${ }^{166}$ See Vanuatu's statement, Report of the Twenty-Ninth Consultative Meeting and the Second Meeting of Contracting Parties, above n 165, at [4.20]; Annex 5.

${ }^{167}$ At [4.23]. 
an iron micro-nutrient. ${ }^{168}$ The respondent's resulting views were divergent, ${ }^{169}$ reflecting the differing approaches, arguments and interpretations that could be made on the matter. This reinforced the issue of uncertainty in the law and helped to illustrate the concerns that were being addressed. Some respondents considered that the activity could fall within the placement exception when there were likely to be purposes, such as climate change mitigation or other commercial reasons such as fisheries enhancement, that were for purposes other than mere disposal. ${ }^{170}$ However other respondents considered that it had the potential to create hazards to human health and to harm living resources and marine life ${ }^{171}$ in defiance of the wording of Article 1 of the Convention, and as a result would be contrary to the aims of the Convention. ${ }^{172}$

\section{The 2008 and 2010 Resolutions}

In 2008 at the Thirtieth Meeting of the Contracting Parties to the London Convention (Third Meeting of the London Protocol) a resolution specifically dealing with the issue of ocean fertilisation was passed. ${ }^{173}$ The resolution explicitly included ocean fertilisation within the scope of the London Convention and Protocol and placed a moratorium on activities other than scientific research. ${ }^{174}$ Moreover the resolution declared that these other activities should be considered as contrary to the aims of the Convention and the Protocol, disqualifying them from the exemptions found therein. ${ }^{175}$ The language adopted by the resolution, "ocean fertilization activities other than legitimate scientific research should not

${ }_{168}$ Report of the Legal and Intersessional Correspondence Group on Ocean Fertilization (LICG), Thirtieth Consultative Meeting of Contracting Parties to the London Convention and Third Meeting of Contracting Parties to the London Protocol, Agenda Item 4, IMO Doc E/LC 30/4 (25 July 2008) at [10].

${ }^{169}$ At [13].

${ }^{170}$ At [13].

${ }^{171}$ At [13].

${ }^{172}$ At [13].

${ }^{173}$ Resolution LC-LP.1 (2008) on the Regulation of Ocean Fertilization (adopted on 31 October 2008).

${ }^{174}$ Resolution LC-LP.1.

${ }^{175}$ Resolution LC-LP.1 at [8]. 
be allowed" 176 carries a tone of suggestion, compared to the use of "shall" in other instruments, which carries the force of imperative. ${ }^{177}$ The Meeting of Contracting Parties also agreed to consider a potentially legally binding resolution or amendment to the London Protocol at its next session. The resolution is an example of soft law, and despite its language is not legally binding. ${ }^{178}$ However scholars such as Scott express the view that it is a highly persuasive instrument and, moreover, relies on more general principles of international environmental law that are independently binding and applicable to all states. ${ }^{179}$

The First Meeting of the London Protocol Intersessional Legal and Related Issues Working Group on Ocean Fertilisation in 2009 considered future courses of action and developed a set of eight options for further review. ${ }^{180}$ These were 1. Statement of concern; 2. Simple resolution; 3. Simple resolution building upon the LC-LP.1 (2008) resolution; 4. Interpretive resolution; 5. Amendment to Annex 1 of the London Protocol; 6. Amendments to Annex 1 and the definition of dumping; 7. Amendments to the definition of dumping and exclusions for dumping; 8. New stand-alone article in the Protocol on ocean fertilisation. ${ }^{181}$

A submission produced by Australia and New Zealand at the Thirty First Consultative Meeting expressed the shared concern that until a legally binding agreement is reached by the Contracting Parties, there is uncertainty of application of the London Convention and Protocol with respect to ocean fertilisation activities. ${ }^{182}$ They considered that a legally

\footnotetext{
${ }^{176}$ At $[8]$.

${ }^{177}$ See for example UNCLOS Article 210(1).

${ }^{178}$ Scott "International Law in the Anthropocene", above n 140, at $332-333$.

${ }^{179}$ At $332-333$.

${ }^{180}$ Report of the First Meeting of the LP Intersessional Legal and Related Issues Working Group on Ocean Fertilization, First Meeting of the LP Intersessional Legal and Related Issues Working Group on Ocean Fertilization, Agenda Item 5, IMO Doc E/LP/CO2 2/5 (20 February 2009) at [3.5].

${ }^{181}$ At [3.5].

${ }^{182}$ Australia and New Zealand Regulating Ocean Fertilization Experiments under the London Protocol and Convention, Submission to the Thirty-First Consultative Meeting of the Contracting Parties of the London
} 
binding regime was not only advantageous for certainty but that it would provide for effective implementation, compliance, monitoring, enforcement and reporting. ${ }^{183}$ The submission canvassed the eight options ruling out the first four due to their non-binding nature. Options 6, 7 and 8 were criticised mainly for temporal reasons, both countries highlighting that the pursuit of these options could involve a process that took many years. ${ }^{184}$ Option 5, amendment of Annex 1 to the London Protocol, was promoted as the best approach due to being the simplest, most expedient, transparent and effective way of regulating legitimate scientific research involving ocean fertilisation. ${ }^{185}$

Australia and New Zealand proposed an amendment to Annex 1 which added a new subparagraph to the annex that enumerated permitted substances adding "material or substances for which the principal intention is ocean fertilization for legitimate scientific research." 186 They noted that the 'placement for a purpose other than' exception was not defined in either the Protocol of Convention and advocated for this language to be interpreted as narrowly as possible but also stressed the importance for Contracting Parties to agree in the adopting resolution, that ocean fertilisation will be considered as dumping and therefore the safe harbour of the exemption limb will be unavailable under either instrument. ${ }^{187}$ This categorisation is a departure from the structure of the Protocol insofar as it speaks of a permitted activity as opposed to a permitted substance. The Second Meeting of the Intersessional Working Group noted further concerns surrounding the circumstances when scientific research can legally be regarded as dumping. ${ }^{188}$

Convention and Fourth Meeting of Contracting Parties to the London Protocol, Agenda Item 4, IMO Doc E/LC 31/4/1 (4 September 2009) at [2].

${ }^{183}$ At [7].

${ }^{184}$ At [5].

${ }^{185}$ At [8].

${ }^{186}$ At [9].

${ }^{187}$ At [11].

${ }^{188}$ Report of the Second Meeting of the LP Intersessional Working Group on Ocean Fertilization, Second Meeting of the LP Intersessional Working Group on Ocean Fertilization, Agenda Item 7, IMO Doc E/LP CO2 3/7 (19 March 2010) at 7. 
A further resolution was made in 2010 which reaffirmed the disqualification of ocean fertilisation activities from the exemption clause and adopted the Assessment Framework for Scientific Research Involving Ocean Fertilization. ${ }^{189}$ However the amendments proposed by Australia and New Zealand were not adopted so that the 2010 resolution left the concerns around the legally binding nature of the resolution unresolved. Annex 6 of the resolution describes a fairly detailed framework that follows a precautionary approach and requires the performance of an environmental impact assessment covering areas such as exposure and effects assessments and risk characterisation and management. The 2010 resolution builds on the 2008 resolution but "nevertheless is not in and of itself binding, and it remains to be seen how the Assessment Framework will be implemented by parties with respect to individual proposed activities. ${ }^{190}$ Despite the legal status of the resolutions, States have demonstrated a general willingness and intention to comply with them. ${ }^{191}$ The non-binding nature of Resolution LC-LP.1 (2008) and Resolution LC-LP.2 (2010) has a further consequence on the law in that they cannot be considered as standards for the purpose of informing Article 210(6) of UNCLOS. ${ }^{192}$ The consequence of this is that the substantive or procedural elements may not be brought to bear on upon States who are only a party to UNCLOS and not the London Convention nor Protocol.

\section{Hard Law and Soft Law - the Relevance of the 2008 and 2010 Resolutions}

Perhaps the most common, or at least the most well-known principal source of international law is the treaty. Treaties create legal obligations, or general norms framed as legal propositions, to govern the conduct of the parties and are binding on those parties. ${ }^{193}$

\footnotetext{
${ }^{189}$ Resolution LC-LP.2 (2010) on the Assessment Framework for Scientific Research Involving Ocean Fertilization (adopted 14 October 2010).

${ }^{190}$ Scott "International Law in the Anthropocene", above n 140, at 351.

${ }^{191}$ Scott "Regulating Ocean Fertilization under International Law: The Risks", above n 114, at 111.

192 At 113.

193 James Crawford Brownlie's Principles of Public International Law ( $8^{\text {th }}$ ed, Oxford University Press, Oxford, 2012) at 31.
} 
Treaties strengthen the force of law between States ${ }^{194}$ and in some instances, for example the beginnings of UNCLOS, ${ }^{195}$ are the codification of customary law. Non-binding instruments, such as resolutions, are sometimes referred to as soft law. International instruments can be analysed by a framework proposed by Abbot et al, which identifies three main elements, precision, obligation, and delegation, all of which help to identify and analyse hard and soft law. ${ }^{196}$ International law can be placed on a continuum. At one end are precise, legally binding treaties which oblige state behaviour through delegated enforcement bodies, or so called hard law, and at the other are non-binding, imprecise, nonenforced soft law at the other.

As seen above, scholars have considered the 2008 and 2010 Resolutions to be non-binding. Furthermore, the discussions of the Contracting Parties have shown that there is considerable concern over the precision element of the Resolutions and some of the proposed amendments, such as the one submitted by Australia and New Zealand. However the dispute resolution mechanisms in Article 16 of the London Protocol provide States with the option of using the Arbitral Procedure or choose to submit themselves to one of the procedures in Article 287 of UNCLOS. ${ }^{197}$ Nevertheless if the dispute relates to Article 3.1 or 3.2 of the Protocol, consent will still be required before the dispute may be settled by the Arbitral Procedure. ${ }^{198}$ Delegated enforcement does exist under the Protocol but the lack of presence in the binding element manifests in the Resolutions being considered as soft law under the above framework.

Non-binding or soft instruments are not altogether impotent on the international plane and can in fact serve many important functions. Non-binding instruments may perform a precursory function in that they act as precursors to the emergence of customary or treaty

\footnotetext{
${ }^{194}$ Andrew Clapham Brierly's Law of Nations ( $7^{\text {th }}$ ed, Oxford University Press, Oxford, 2012) at 56.

195 Tanaka, above n 81, at 20.

${ }^{196}$ Kenneth W. Abbot and others "The Concept of Legalization” (2000) 54 International Organisation 401.

${ }^{197}$ London Protocol, art 16.

${ }^{198}$ London Protocol, art 16(5).
} 
law. ${ }^{199}$ It is unlikely that resolutions relating to ocean iron fertilisation could be considered as declaratory of customary law. However the adoption of non-binding instruments is often a first step in the development of treaty law. ${ }^{200}$ The 2008 and 2010 Resolutions act as restraint on future discussions and guide State Parties toward an eventual conclusion or at least a convergence. Resolutions also do not require ratification and so are more expedient when compared with harder instruments such as treaties. This may help norms to evolve faster. They may act as catalysts for treaty making behaviour since once States realise that a proposed system is feasible, the move towards harder law usually requires a reduced amount of political will. ${ }^{201}$

Nonbinding instruments also provide a supplementary function, where the law is insufficiently precise, by providing concretisations or guidance for interpretation. ${ }^{202}$ The 2008 and 2010 Resolutions could be considered as offering a guidance function in the interpretation of the London Protocol, by confirming that the scope of the Protocol clearly covers ocean iron fertilisation and limits conduct to small-scale scientific research only. This proposition may be strengthened by further considerations of the Vienna Convention on the Law of Treaties. The relevant Article provides:203

3. There shall be taken into account, together with the context:

(a) any subsequent agreement between the parties regarding the interpretation of the treaty or the application of its provisions;

(b) any subsequent practice in the application of the treaty which establishes the agreement of the parties regarding its interpretation;

Both the 2008 and 2010 Resolutions may be considered as agreements between the parties. The language of the 2008 Resolution is rather clear in its attempt to define the scope of the

199 Jurgen Friedrich International Environmental "Soft Law" the Functions and Limits of Nonbinding Instruments in International Environmental Governance and Law (Springer, Heidelberg, 2013) at 143.

${ }^{200}$ At 157.

${ }^{201}$ At 158 .

202 At 171.

${ }^{203}$ Vienna Convention, art 31(3). 
activity that is prohibited under the Protocol. Firstly it defines ocean fertilisation as "any activity undertaken by humans with the principle intention of stimulating primary productivity in the oceans." ${ }^{204}$ Secondly, it brings these activities under the Protocol ${ }^{205}$ and thirdly, declares that only legitimate scientific research should be regarded as placement of matter for a purpose other than the mere disposal thereof. ${ }^{206}$ The 2008 Resolution does not explicitly say in satisfaction of the Vienna Convention "the Parties interpret the Protocol as..." but must at least be taken as providing an implicit interpretation. If this analysis is correct, the 2008 and 2010 Resolutions themselves may not necessarily be binding instruments, nevertheless their interpretive effect on the London Protocol may assist in increasing the weight of the binding element under the Abbott et al framework, therefore shifting it further along the spectrum towards hard law. The cumulative effect of this may be to aggregate the London Protocol with the 2008 and 2010 Resolutions to form a binding instrument.

This alternative analysis is still peppered with uncertainty, the same kind of uncertainty that led to the submission by Australia and New Zealand, seeking an unequivocal, binding change to the Protocol. Option 4, the Interpretive Resolution, was itself concerned with making an agreed interpretation under Article 31(3)(a) of the Vienna Convention. ${ }^{207}$ Although this option was not seen as being strong enough by Australia and New Zealand, it would at least remove the need for the preceding analysis, leaving the admissibility and applicability of the Resolutions, under Article 31(3)(a), in no doubt. As it stands, the point is still arguable.

The precautionary principle has only been treated peripherally in the previous discussion. This principle will now be examined to explore its relationship with the CBD and to see how it informs the legal framework.

\footnotetext{
${ }^{204}$ Resolution LC-LP.1 at [2].

205 At [1].

206 At [3].

${ }^{207}$ Intersessional Working Group, above n 188, at [5].
} 


\section{$D$ The Precautionary Principle and the Convention on Biological Diversity}

It is not certain whether the precautionary principle comprises customary international law or whether UNCLOS must be interpreted to reflect a precautionary approach. ${ }^{208}$ Although treaty interpretation may take into account developments in customary international law, an interpretation must not conflict with the intentions and expectations of the parties at the time of negotiation. ${ }^{209}$ Despite an application of the principle, iron fertilisation activities may still come within the exclusionary part of the definition of 'dumping'. The precautionary principle states that where threats of serious or irreversible damage exist, a lack of scientific certainty shall not be used as a reason for postponing cost-effective measures to prevent environmental degradation. ${ }^{210}$ For ocean iron fertilisation, this means that insufficient scientific certainty relating to the possible environmental harm from the conduct, cannot be used as a factor pointing towards the permissible use of that conduct.

One of the main distinguishing features between the London Convention and the London Protocol is that the latter is founded on the precautionary principle. Article 3 of the London Protocol requires Contracting Parties to apply a precautionary approach to environmental protection from dumping and to take preventative measures where the introduction is likely to cause harm even where there is no conclusive evidence to prove a causal relationship. ${ }^{211}$ Australia and New Zealand considered the Protocol to be a framework that is precautionary, yet flexible in that it allows for the regulation of activities that were unforeseen by the Contracting Parties at the time of adoption, whilst ensuring precautionary protection of the marine environment. ${ }^{212}$ The drafters of the Protocol saw it fit to specifically include the principle, presumably to avoid any doubt associated with its

\footnotetext{
${ }^{208}$ Karen Scott "The Day After Tomorrow: Ocean CO2 Sequestration and the Future of climate Change" (2005) 18 Georgetown International Law Review 57 at 70.

${ }^{209}$ At 70.

${ }^{210}$ Abate and Greenlee, "Sowing Seeds Uncertain”, above n 91, at 574.

${ }^{211}$ London Protocol, art 3.

${ }^{212}$ Australia and New Zealand Regulating Ocean Fertilization Experiments under the London Protocol and Convention, above n 182, at [9].
} 
application as customary international law. Iron fertilisation activities may be influenced by the principle but may still fall outside the exclusionary part of the definition as discussed above. The principle itself is not expressly contained in UNCLOS. ${ }^{213}$ However scholars have argued that the obligations to prevent pollution are triggered even without the existence of a proved causal link between the activity and the harm, so long as that environmental harm is likely. ${ }^{214}$

Decision IX/16 of the $9^{\text {th }}$ Meeting of the Conference of the Parties to the Convention on Biological Diversity specifically considered ocean fertilisation and requested Parties and urged Governments: ${ }^{215}$

...in accordance with the precautionary approach, to ensure that ocean fertilization activities do not take place until there is an adequate scientific basis on which to justify such activities, including assessing associated risks, and a global, transparent and effective control and regulatory mechanism is in place for these activities; with the exception of small scale scientific research studies within coastal waters. Such studies should only be authorized if justified by the need to gather specific scientific data, and should also be subject to a thorough prior assessment of the potential impacts of the research studies on the marine environment, and be strictly controlled, and not be used for generating and selling carbon offsets or any other commercial purposes;

There are several differences between the CBD decision and the London Protocol, in general, the former being more restrictive than the later. Experiments must be small scale, large scale experiments are not justified, and these experiments must be undertaken within coastal waters. A thorough prior assessment is required, which is similar to what is required under the London Protocol. Most notably is the requirement that commercial purposes such as the generation and selling of carbon offsets is prohibited. No mention of commercial prohibitions can be found in the other instruments.

\footnotetext{
${ }^{213}$ Scott “The Day after Tomorrow", above n 208, at 69.

${ }^{214}$ At 70 .

${ }^{215}$ Decision IX/16 of the $9^{\text {th }}$ Meeting of the Conference of the Parties to the Convention on Biological Diversity (CBD IX/16) at [C].
} 


\section{E Conclusion on Ocean Iron Fertilisation under the Current Law}

The position of ocean iron fertilisation under the instruments analysed is far from crystal clear. Recent submissions, such as the one from Australia, Nigeria and the Republic of Korea, proposing an amendment of the protocol to effect legally binding regulation of ocean fertilisation ${ }^{216}$ are testament to this. Under UNCLOS, State behaviour may fall within the exclusionary limb of "dumping". Ocean iron fertilisation activities may also be allowed under the general permit section under the London Convention or under the London Protocol through the exemption limb. However it is arguable that the subsequent Resolutions in 2008 and 2010, despite being generally considered as non-binding, may assist in the interpretation of the Protocol such that only legitimate scientific experiments are permitted. The fact that States have willingly subjected themselves to both Resolutions should also carry weight. The CBD also proscribes ocean fertilisation conduct. States who are not party to any of these instruments will be subject to obligations under customary international law. Customary law contains only general rule relevant to the issue, the most important of which is that no State has the right to use or permit the use of its territory in such a manner as to cause injury in or to the territory of another State. ${ }^{217}$

There is a sense of incompleteness about the London Convention and Protocol. The current state appears to be a stopgap where what is needed is a more comprehensive solution. The uncertainty in the law allows states to point to the exemption clauses or rely on the nonbinding nature or the Resolutions if they decide that is desirable. The next part will illustrate this further, highlighting the difficulty in the application of the law in its present state to real world fact patterns.

216 Australia, Nigeria and Republic of Korea Regulation of Ocean Fertilization and Other Activities, Submission to the Thirty-Fifth Consultative Meeting of Contracting Parties to the London Convention and Eighth Meeting of Contracting Parties to the London Protocol, Agenda Item 4, IMO Doc E/LC 35/4 (11 April 2013).

217 Tanaka, above n 81, at 260. 


\section{Effectiveness of the Law at Regulating Ocean Iron Fertilisation - Contemporary Examples}

This section will look at the law's response to instances of ocean iron fertilisation to evaluate its efficacy in proscribing this behaviour. It looks at two examples in particular, the LOHAFEX experiment and the Haida Salmon Restoration Corporation case.

\section{A The LOHAFEX Experiment}

The LOHAFEX experiment was an ocean iron fertilisation experiment conducted by German and Indian scientists from the Alfred Wegener Institut, in the Southern Ocean in 2009. ${ }^{218}$ The LOHAFEX scientists submitted their proposal to the German government, claiming that the experiment complied with international guidelines provided by the London Convention and Protocol and the CBD Decision IX/16. ${ }^{219}$ To fall within the CBD, the practice needed to be "small-scale" and within "coastal waters". 220 The German Environmental Ministry based its decision on these requirements and concluded that the experiment would not comply with a strict interpretation of CBD Decision IX/16. ${ }^{221}$ However under the London Convention and Protocol, ocean iron fertilisation activities were permissible as legitimate scientific research. It was on this basis then, recognising the disparity between the CBD and the Convention and Protocol, that the German Ministry of Research reversed the German Environmental Ministry's decision and allowed the activity to proceed. ${ }^{222}$ In what may be seen as a small step backwards, the CBD despite expressing

\footnotetext{
${ }^{218}$ Alfred-Wegener-Institut "LOHAFEX: An Indo-German iron fertilization experiment - what are the effects?"<http://www.awi.de/en/news/press_releases/detail/item/lohafex_an_indo_german_iron_fertilizatio n_experiment_what_are_the_effects_on_the_ecology_and_carb/?cHash $=725 \mathrm{a} 5 \mathrm{~b} 9368>$

${ }^{219}$ Michael C. Branson "A Green Herring: How Current Ocean Fertilization Regulation Distracts From Geoengineering Research” (2014) 54 Santa Clara L. Rev. 163 at $177-178$.

${ }^{220} \mathrm{CBD}$ IX/16 at [C].

${ }^{221}$ Abate and Greenlee, "Sowing Seeds Uncertain", above n 91, at 586.

${ }^{222}$ Branson "A Green Herring”, above n 219, at 178.
} 
strong caution against geoengineering projects, acquiesced to the London Convention and London Protocol assessment framework for ocean fertilisation projects. ${ }^{223}$

On the one hand, the LOHAFEX incident may show the influence that international instruments have had on actors. The scientists involved did attempt to bring their activities with the scope of the law, although some of their contentions, for example that activities taking place in waters that contained coastal plankton species satisfied the "coastal waters" criterion under the $\mathrm{CBD}^{224}$, were tenuous at best. The London Convention and Protocol do not carry the same restrictive criteria as the $\mathrm{CBD}$ and a legal justification for the experiments is likely to be successful under these instruments as scientific experiments, notwithstanding the lack of guidance over what quantities of iron may or may not cross the threshold from legitimate scientific research to illegitimate dumping.

On the other hand, the LOHAFEX incident shows the lack of harmonisation between instruments and the results that this can cause. Parties may take advantage of ambiguities or incongruities between instruments by forcing themselves through the gaps which were once thought to be non-existent among overlapping instruments. Although the CBD relaxed its criteria surrounding ocean iron fertilisation experiments, the LOHAFEX incident arguably illustrates a successful application of the law under the London Convention and Protocol.

\section{B The Haida Salmon Restoration Corporation Case}

The main fear amongst ocean iron fertilisation activities is unilateral conduct. In 2012, the Haida Salmon Restoration Corporation (HSRC), an incarnation of former Planktos CEO Russ George, dumped 100 tonnes of iron sulphate into the Pacific Ocean off the Canadian west coast. ${ }^{225}$ The scheme was purported to increase the salmon population and to sequester

\footnotetext{
223 At 179 .

${ }^{224}$ Abate and Greenlee, "Sowing Seeds Uncertain", above n 91, at 586.

225 Jeff Tollefson "Ocean-fertilization Project off Canada Sparks Furore”
} 
carbon dioxide through the creation of a phytoplankton bloom. ${ }^{226}$ HSRC gained widespread attention, not only for the iron fertilisation, but for their public statements indicating their plan to generate revenue by attempting to sell carbon credits on the international market for the carbon dioxide sequestered by the project. ${ }^{227}$ Environmental Canada, the domestic regulator, admitted to being involved in preliminary discussions but indicated that no approvals for the activity were sought or granted. ${ }^{228}$

The issue was addressed by Canada at the $34^{\text {th }}$ Consultative Meeting of the Contracting Parties to the London Convention and Seventh Meeting of Contracting Parties to the London Protocol. ${ }^{229}$ In its statement, Canada reaffirmed its agreement with the 2008 and 2010 Resolutions, in that ocean fertilisation activities other than legitimate scientific research should not be allowed. ${ }^{230}$ Moreover, Canada expressed its agreement that activities other than those assessed under the 2010 Assessment Framework, should be considered as contrary to the aims of the Convention and Protocol and would not qualify for any exemption from the definition of dumping. ${ }^{231}$ The Government of Canada stressed that it did not authorise the activity or receive any details that would have allowed an assessment of the project and that an investigation by Environment Canada's Enforcement Branch was underway. ${ }^{232}$

$<$ http://www.nature.com/news/ocean-fertilization-project-off-canada-sparks-furore-1.11631>.

${ }^{226}$ Scott "Regulating Ocean Fertilization under International Law: The Risks", above n 114, at 108.

${ }^{227}$ Neil Craik and Jason Blackstock and Anna-Maria Hubert "Regulating Geoengineering Research through Domestic Environmental Protection Frameworks: Reflections on the Recent Canadian Ocean Fertilization Case" (2013) 2 CCLR 117 at 118.

228 At 118 .

${ }^{229}$ Report of the Thirty-Fourth Consultative Meeting and the Seventh Meeting of Contracting Parties, ThirtyFourth Consultative Meeting of Contracting Parties to the London Convention and Seventh Meeting of Contracting Parties to the London Protocol, Agenda Item 15, IMO Doc E/LC 34/15 (23 November 2012) at Annex 3 .

${ }^{230}$ At Annex 3.

231 At Annex 3.

232 At Annex 3. 
In 2013 Environment Canada executed a search warrant on HSRC offices and seized a number of documents with HSRC filing suit for their return. ${ }^{233}$ No case has been heard on the substantive dumping allegations however the decision in Haida Salmon Restoration Corp $v$ Canada (Environment Canada) ${ }^{234}$ relating to an application by HSRC to have the search warrant for its premises set aside, provides some insight into the issues that the Court will have to tackle at a later stage and how Canada's domestic legislation may operate. The Canadian Environmental Protection Act $1999^{235}$ (CEPA) is the instrument responsible for the domestic implementation of the London Convention and Protocol in Canada. ${ }^{236}$

The core issue in the case was whether or not the search warrant was based on an offence known to Canadian law, ${ }^{237}$ which required the Court to examine whether the introduction of the iron was contrary to Canadian law, in particular CEPA. Voith J held that CEPA was applicable insofar as the ship was loaded in Canada and was a Canadian ship, and that the provisions applied to HSRC irrespective of whether the disposal occurred within or outside of waters under the jurisdiction of any state. ${ }^{238}$ Voith $\mathrm{J}$ went on to state the proposition that the regime prohibited the disposal of substances at sea without a permit, except for the limited exception where that placement is for a purpose other than the mere disposal and is not contrary to the aims of the Convention or Protocol. ${ }^{239}$

Voith J outlined Article 31 of the Vienna Convention, highlighting its effect on treaty interpretation and inferred that the 2008 and 2010 Resolutions may be relevant in informing the interpretation of the Protocol and Convention yet expressed no final opinion on the

\footnotetext{
$\overline{{ }^{233} \text { Craik and Blackstock and Hubert "Regulating Geoengineering Research through Domestic Environmental }}$ Protection Frameworks", above n 227, at 118.

${ }^{234}$ Haida Salmon Restoration Corp v Canada (Environment Canada) 2014 BCSC 151.

${ }^{235}$ Canadian Environmental Protection Act, 1999, S.C. 1999, c. 33. [CEPA].

${ }^{236}$ See CEPA s 122.1.

${ }^{237}$ Haida, above n 234, at [33].

238 At [9].

239 At [13].
} 
matter ${ }^{240}$ mainly because only the basic elements of the offence at issue had to be made out in order to deny the Applicant's relief. ${ }^{241}$ The principle of conformity, the rebuttable presumption that Canadian legislation is expected to conform with Canada's international law obligations, was also raised with Voith J holding that the 2008 and 2010 Resolutions would be relevant to this determination. ${ }^{242}$ This was one of the points raised by the Respondents, namely, that the 2008 and 2010 Resolutions informed the interpretation of the obligations contained in CEPA, through an application of the principle of conformity. ${ }^{243}$ Voith $\mathrm{J}$ also placed some weight on the amount of material disposed of, noting that it was an order of magnitude larger than other examples that had constituted legitimate scientific research. ${ }^{244}$ The basic elements of the offence were held to be present and the application to set aside the search warrant was dismissed.

The case demonstrates the complexities and uncertainty that exists in the domestic application of international instruments in the field of ocean iron fertilisation. No express opinion is provided although the case does cover some of the main points of difficulty. However, one is left with the impression that a Canadian court may be willing to interpret Canada's international obligations, through the domestic framework in a manner that would hold the activities of HSRC in breach of Canadian law.

The LOHAFEX experiment highlights the problems that can arise due to a lack of harmonisation between international instruments that address the same behaviour. The HSRC project and subsequent litigation in Haida Salmon Restoration Corp v Canada (Environment Canada) demonstrates the difficulties in applying the London Convention and Protocol as implemented in domestic legislation such as CEPA. It is not entirely clear how the 2008 and 2010 Resolutions would inform an interpretation of domestic law in fulfilment of international obligations concerning ocean iron fertilisation. In both cases, the

\footnotetext{
${ }^{240}$ At [52].

${ }^{241}$ At [33].

${ }^{242}$ At [21].

${ }^{243}$ At [41].

${ }^{244}$ At [44].
} 
aims of the Convention and Protocol may be frustrated, reducing the effectiveness of the instruments. On the one hand, through incongruity and the other, lack of clarity and certainty. The next section will look at some possible measures that may improve the law in the area of ocean iron fertilisation and geoengineering governance in general.

\section{$V$ Measures to Strengthen the Law}

\section{A Fragmentation of Global Governance Architectures}

Fragmentation is a frequent characteristic of global governance architectures often represented by the overall institutional setting in which distinct institutions interact. ${ }^{245}$ Environmental law is seen as an example of this with reference being made to the multiplicity of global environmental governance. ${ }^{246}$ The core instrument in international law relating to climate change, is the UNFCCC. However this instrument does not cover ocean iron fertilisation. The London Convention and Protocol address ocean iron fertilisation but due to their limited scope, cannot extend to govern research for most land and atmosphere-based geoengineering models. ${ }^{247}$ An obvious solution may be to attempt to incorporate ocean iron fertilisation into a new treaty on geoengineering. However the challenges of negotiating a new treaty on geoengineering means that governance is more likely to develop through the extension of existing regimes, rather than through the adoption of a single comprehensive regime. ${ }^{248}$ Furthermore, placing geoengineering regimes under the umbrella of the UNFCCC is seen as implausible by some scholars since

\footnotetext{
${ }^{245}$ Frank Biermann and Philipp Pattberg and Harro van Asselt "The Fragmentation of Global Governance Architectures: A Framework for Analysis" (2009) 9 Global Environmental Politics 14 at 17.

${ }^{246}$ At 17.

${ }^{247}$ Erin Tanimura "Geoengineering Research Governance: Foundation, Form and Forum" (2013) 37 Environs Envtl. L. \& Pol'y J. 167 at $191-192$.

${ }^{248}$ Daniel Bodansky “The Who, What, and Wherefore of Geoengineering Governance" (2013) 121 Climatic Change 539 at 550.
} 
the UNFCCC "is seen as dysfunctional by many countries, and few trust its ability to make decisions. ${ }^{249}$

However, the fragmentation of global governance architectures can lead to regulatory gaps as seen in the incongruity between the CBD and the London Convention and Protocol. Australia and New Zealand, in their submission to the $31^{\text {st }}$ Consultative Meeting of the Contracting Parties noted the CBD Decision IX/16 and considered that "unequivocal legal certainty through an international instrument should be achieved as soon as possible and that the London Protocol and Convention provide the appropriate global mechanism."250 Conflicting approaches by different treaties to the same geoengineering technique can cause regulatory problems but insofar as those treaties are concerned with different geoengineering technologies, the potential for conflict may be limited. ${ }^{251}$

In terms of moving forwards, the foregoing discussion suggests that the best approach to ocean iron fertilisation governance would be to continue to focus on the London Convention and Protocol. This would save the time and cost of negotiating a new treaty and would eliminate issues of harmonisation that may occur when governance of the same geoengineering technique is spread across different instruments.

\section{B Option Proposed by Australia and New Zealand}

The adoption of the proposal by Australia and New Zealand is a relatively clean option. This amendment has the least impact on the instruments as it requires only a minor change to the annex and has the advantage of producing a binding instrument for the governance of ocean iron fertilisation. Parties will not be subject to the same time and cost concerns that would accompany the negotiation of a new instrument.

\footnotetext{
${ }^{249}$ At 550.

${ }^{250}$ Australia and New Zealand Regulating Ocean Fertilization Experiments under the London Protocol and Convention, above n 182, at [3].

${ }^{251}$ Honegger "Tackling Climate Change" at 130.
} 


\section{Strengthening Domestic Law}

International obligations are implemented at the State level through domestic law. It is open to a State to amend its domestic law to narrow the scope of permitted activities, for example a State may introduce more stringent restrictions on substances that may be dumped in its waters or from its flagged vessels. Returning to the HSRC case, the CEPA regime may be assessed by the sufficiency of its coverage, the clarity of its rules and the ease by which enforcement may proceed. ${ }^{252}$ Jurisdictionally, the coverage is extensive as the prescriptive jurisdiction includes activities on the high seas and in foreign waters undertaken by Canadian flagged vessels, while substantively, the coverage is narrow in that it only addresses ocean fertilisation, ${ }^{253}$ although admittedly this is the activity at issue here. The Canadian approach is indicative of the high degree of fragmentation occurring in relation to geoengineering at the international level, where there is no clear regulatory body. ${ }^{254}$

Environment Canada has released an information bulletin clarifying its interpretation of CEPA in accordance with international obligations, however it has no formal legal form under Canadian law and as such is only well suited to those actors who are predisposed to comply voluntarily. ${ }^{255}$ The implications of this can be applied to other States' domestic regulations that are designed to implement the Convention and Protocol. Informal notices and statements of interpretation are not of sufficient legal force. To remove doubt and increase certainty, these statements need to take the form of formal legal regulations that reinforce the content of the 2008 and 2010 Resolutions. This reflects the decentralised nature of international law, rather than providing centralised enforcement mechanisms,

$\overline{{ }^{252} \text { Craik and Blackstock and Hubert "Regulating Geoengineering Research through Domestic Environmental }}$ Protection Frameworks", above n 227, at 121.

${ }^{253}$ At 121 .

${ }^{254}$ At 121.

${ }^{255}$ At 122 - 123. 
treaties rely on States to police the activities of actors within their jurisdiction. ${ }^{256}$ States only have to summon the necessary political will in order to effect appropriate changes.

\section{Economic Considerations}

The Legal and Intersessional Correspondence Group on Ocean Fertilization (LICG), in its 2008 report, highlighted comments made by the CBD that ocean iron fertilisation activities must be strictly controlled and not used for generating and selling carbon offsets or any other commercial purpose. ${ }^{257}$ In noting the absence of any reference to commercial activities under the London Convention and Protocol, the LICG stressed that "it is considered urgent to agree the concept of regulation such that commercially driven activities are prohibited. ${ }^{258}$ Projects such as those contemplated or performed by companies such as Planktos and HSRC, may be stifled, if not eliminated, if the economic incentive is removed. This would involve placing a blanket prohibition on the creation of carbon credits from ocean iron fertilisation activities, therefore increasing the likelihood that only legitimate scientific experiments would proceed. These experiments may of course be motivated by profit but any future profits will only be derived once the activity has passed through appropriate scrutiny. A prohibition on carbon credits derived from iron fertilisation will assist in deterring reckless, unilateral activity in pursuit of quick profits.

\section{Conclusion}

Geoengineering is one of the potential choices in the portfolio of climate change mitigation options. Ocean iron fertilisation is only one of the techniques available but has proven to be an attractive option due to its relatively low cost. However, the low cost and promise of economic riches has led to concerning unilateral conduct. The effects of large scale

\footnotetext{
${ }^{256}$ Abate and Greenlee, "Sowing Seeds Uncertain”, above n 91, at 587.

${ }^{257}$ Report of the Legal and Intersessional Correspondence Group on Ocean Fertilization (LICG), above n 168.

${ }^{258}$ At [33].
} 
fertilisation are largely unknown although the potential for catastrophe is significant. The current legal framework under UNLCOS and the London Convention and Protocol does not provide for clear, certain outcomes regarding the regulation of ocean iron fertilisation activities. This paper has argued that although the 2008 and 2010 Resolutions are a step in the right direction in terms of forming binding law, they have not gone far enough. The certainty that the law requires, in order to promote desirable behaviour, such as legitimate scientific experiments, and to proscribe undesirable conduct, is currently absent. Four approaches have been suggested that will increase the clarity and certainty of the law. Firstly, the regulation of iron ocean fertilisation should be contained within the one instrument, the most appropriate being the London Convention and Protocol. Secondly, the law may be clarified by adopting the recommendations contained in the submission from Australia and New Zealand. Thirdly, States may take the initiative and strengthen their domestic legislation. Fourthly, removal of economic incentives via the global carbon markets will eliminate speculative, unilateral conduct. 


\section{Bibliography}

A Cases

1 Canada

Haida Salmon Restoration Corp v Canada (Environment Canada) 2014 BCSC 151.

B Legislation

1 Canada

Canadian Environmental Protection Act, 1999, S.C. 1999, c. 33.

\section{United States}

Marine Protection, Research, and Sanctuaries Act 1972.

C International Instruments

1992 Convention on Biological Diversity 1760 UNTS 79 (opened for signature 5 June 1992, entered into force 29 December 1993).

1972 Convention on the Prevention of Marine Pollution by Dumping of Wastes and Other Matter 1046 UNTS 120 (opened for signature 29 December 1972, entered into force 30 August 1975).

Convention on the Prohibition of Military or Any Other Hostile Use of Environmental Modification Techniques 1108 UNTS 151 (opened for signature 18 May 1977, entered into force 5 October 1978). 
Decision IX/16 of the $9^{\text {th }}$ Meeting of the Conference of the Parties to the Convention on Biological Diversity.

1997 Kyoto Protocol to the UN Framework Convention on Climate Change 2303 UNTS 148 (opened for signature 11 December 1997, entered into force 16 February 2005).

1996 Protocol to the 1972 Convention on the Prevention of Marine Pollution by Dumping of Wastes and Other Matter 2006 ATS 11 (opened for signature 7 November 1996, entered into force 24 March 2006).

Resolution LC-LP.1 (2008) on the Regulation of Ocean Fertilization (adopted on 31 October 2008).

Resolution LC-LP.2 (2010) on the Assessment Framework for Scientific Research Involving Ocean Fertilization (adopted 14 October 2010).

United Nations Convention on the Law of the Sea (UNCLOS) 1833 UNTS 3 (opened for signature 10 December 1982, entered into force 16 November 1994).

1992 United Nations Framework Convention in Climate Change 1771 UNTS 107 (opened for signature 9 May 1992, entered into force 21 March 1994).

Vienna Convention on the Law of Treaties 1155 UNTS 331 (opened for signature 23 May 1969, entered into force 27 January 1980).

\section{Other International Materials}

Australia and New Zealand Regulating Ocean Fertilization Experiments under the London Protocol and Convention, LC 31/4/1 Submission to the Thirty-First Consultative Meeting 
of the Contracting Parties of the London Convention and Fourth Meeting of Contracting Parties to the London Protocol, Agenda Item 4, IMO Doc E/LC 31/4/1 (4 September 2009).

Australia, Nigeria and Republic of Korea Regulation of Ocean Fertilization and Other Activities, Submission to the Thirty-Fifth Consultative Meeting of Contracting Parties to the London Convention and Eighth Meeting of Contracting Parties to the London Protocol, Agenda Item 4, IMO Doc E/LC 35/4 (11 April 2013).

Greenpeace International Ocean Disposal/Sequestration of Carbon Dioxide, Submission to the Scientific Group of the London Convention, $22^{\text {nd }}$ Meeting, Agenda Item 11, IMO Doc E/LC/SG 22/INF .20 (19 March 1999).

Oceans and the Law of the Sea-Report of the Secretary-General, $63^{\text {rd }}$ sess, Agenda Item 73(a), UN DOC A/63/63/Add. 1 (29 August 2008).

Report of the First Meeting of the LP Intersessional Legal and Related Issues Working Group on Ocean Fertilization, First Meeting of the LP Intersessional Legal and Related Issues Working Group on Ocean Fertilization, Agenda Item 5, IMO Doc E/LP/CO2 2/5 (20 February 2009).

Report of the Legal and Intersessional Correspondence Group on Ocean Fertilization (LICG), Thirtieth Consultative Meeting of Contracting Parties to the London Convention and Third Meeting of Contracting Parties to the London Protocol, Agenda Item 4, IMO Doc E/LC 30/4 (25 July 2008).

Report of the Second Meeting of the LP Intersessional Working Group on Ocean Fertilization, Second Meeting of the LP Intersessional Working Group on Ocean Fertilization, Agenda Item 7, IMO Doc E/LP CO2 3/7 (19 March 2010).

Report of the Thirty-Fourth Consultative Meeting and the Seventh Meeting of Contracting Parties, Thirty-Fourth Consultative Meeting of Contracting Parties to the London 
Convention and Seventh Meeting of Contracting Parties to the London Protocol, Agenda Item 15, IMO Doc E/LC 34/15 (23 November 2012).

Report of the Twenty-First Consultative Meeting, Twenty-First Consultative Meeting of Contracting Parties to the Convention on the Prevention of Marine Pollution by Dumping of Wastes and Other Matter, Agenda Item 13, IMO Doc E/LC 21/13 (1 November 1999).

Report of the Twenty-Second Meeting of the Scientific Group of the London Convention, Scientific Group of the London Convention, $22^{\text {nd }}$ Meeting, Agenda Item 13, IMO Doc E/LC/SG 22/13 (10 June 1999).

Report of the Thirtieth Meeting of the Scientific Group of the London Convention and the First Meeting of the Scientific Group of the London Protocol, Scientific Group of the London Convention $-30^{\text {th }}$ Meeting and Scientific Group of the London Protocol $-1^{\text {st }}$ Meeting, Agenda Item 14, IMO Doc E/LC/SG 30/14 (25 July).

Report of the Twenty-Ninth Consultative Meeting and the Second Meeting of Contracting Parties, Twenty-Ninth Consultative Meeting of Contracting Parties to the London Convention and Second Meeting of Contracting Parties to the London Protocol, Agenda Item 17, IMO Doc E/LC 29/17 (14 December 2007).

Statement of Concern Regarding Iron Fertilization of the Oceans to Sequester $\mathrm{CO}_{2}$, Scientific Groups of the London Convention and London Protocol, IMO Doc E/LCLP.1/Circ.14 (13 July 2007).

United States Planktos, Inc., Large-scale Ocean Iron Addition Projects, Submission to the Scientific Group of the London Convention $30^{\text {th }}$ Meeting, Agenda Item 12, IMO Doc E/LC/SG 30/INF.28 (1 June 2007). 
E Books and Chapters in Books

Iain M. Banks The Algebraist (Orbit, UK, 2004).

Andrew Clapham Brierly's Law of Nations ( $7^{\text {th }}$ ed, Oxford University Press, Oxford, 2012)

James Crawford Brownlie's Principles of Public International Law $\left(8^{\text {th }}\right.$ ed, Oxford University Press, Oxford, 2012).

Robert H. Frank and Ben S. Bernanke Principles of Economics (2nd ed, McGrawHill/Irwin, New York, 2004).

Jurgen Friedrich International Environmental "Soft Law" the Functions and Limits of Nonbinding Instruments in International Environmental Governance and Law (Springer, Heidelberg, 2013).

Natalie Klein, Joanna Mossop and Donald R. Rothwell (eds) Maritime Security: International Law and Policy Perspectives from Australia and New Zealand (Routledge, Oxon, 2010).

Donald R. Prothero and Scott E. Foss The Evolution of Artiodactyls (The Johns Hopkins University Press, Maryland, 2007).

David R. Rothwell and Tim Stephens The International Law of the Sea (Hart Publishing, Oregon, 2010).

Yoshifumi Tanaka The International Law of the Sea (Cambridge University Press, New York, 2012). 


\section{F Journal Articles}

Randall S. Abate and Andrew B. Greenlee "Sowing Seeds Uncertain: Ocean Iron Fertilization, Climate Change, and the International Environmental Law Framework" (2010) 27 Pace Envtl. L. Rev. 555.

Kenneth W. Abbot and others "The Concept of Legalization" (2000) 54 International Organisation 401.

Scott Barrett “The Incredible Economics of Geoengineering” (2008) 39 Environ Resource Econ 45.

Frank Biermann and Philipp Pattberg and Harro van Asselt "The Fragmentation of Global Governance Architectures: A Framework for Analysis" (2009) 9 Global Environmental Politics 14.

Daniel Bodansky "The Who, What, and Wherefore of Geoengineering Governance" (2013) 121 Climatic Change 539.

Olivier Boucher and others "Rethinking Climate Engineering Categorization in the Context of Climate Change Mitigation and Adaptation” (2013) WIREs Clim Change 2.

Michael C. Branson "A Green Herring: How Current Ocean Fertilization Regulation Distracts From Geoengineering Research” (2014) 54 Santa Clara L. Rev. 163.

Adam Corner and Nick Pidgeon "Geoengineering the Climate: The Social and Ethical Implications" (2010) 52 Environment 25.

Anthony Costello and others "Managing the Health Effects of Climate Change" (2009) 373 The Lancet 1693. 
Neil Craik and Jason Blackstock and Anna-Maria Hubert "Regulating Geoengineering Research through Domestic Environmental Protection Frameworks: Reflections on the Recent Canadian Ocean Fertilization Case" (2013) 2 CCLR 117.

Duncan E.J. Currie and Keteryna Wowk "Climate Change and $\mathrm{CO}_{2}$ in the Oceans and Global Oceans Governance (2009) 4 CCLR 387.

Louise de La Fayette "The London Convention 1972: Preparing for the Future" (1998) 13 Int'1 J. Marine \& Coastal L. 515.

David Freestone and Rosemary Rayfuse "Ocean Iron Fertilization and International Law" (2008) 364 Mar Ecol Prog Ser 227.

Dr. Harald Ginzky "Ocean Fertilization as Climate Change Mitigation Measure Consideration under International Law" (2010) 7 J. Eur. Envtl. \& Plan. L. 57.

Xueliang Guo and Guoguang Zheng and Dezhen Jin "A Numerical Comparison Study of Cloud Seeding by Silver Iodide and Liquid Carbon Dioxide" (2006) 79 Atmospheric Research 183.

Matthias Honegger and Kushini Sugathapala and Axel Michaelowa "Tackling Climate Change: Where can the Generic Framework be Located?"(2013) 2 CCLR 125.

Timothy M. Lenton and Naomi E. Vaughan "A Review of Climate Geoengineering Proposals" (2011) 109 Climatic Change 745.

Albert C. Lin “Does Geoengineering Present a Moral Hazard?” (2013) 40 Ecology LQ 673.

Ty McCormick “Anthropology of an Idea: Geoengineering” (2013) 202 Foreign Policy 28. 
James Edward Peterson "Can Algae Save Civilization? A Look at Technology, Law, and Policy Regarding Iron Fertilization of the Ocean to Counteract the Greenhouse Effect" (1995) 6 Colo. J. Int'l Envtl. L. \& Pol'y 61.

Jules Pretty "The Consumption of a Finite Planet: Well-Being, Convergence, Divergence and the Nascent Green Economy" (2013) 55 Environ Resource Econ 475.

Rosemary Rayfuse "Drowning Our Sorrows to Secure a Carbon Free Future? Some International Legal Considerations Relating to Sequestering Carbon by Fertilising the Oceans" (2008) 31 UNSW LJ 919.

Rosemary Rayfuse and Mark G. Lawrence and Kristina M. Gjerde "Ocean Fertilisation and Climate Change: The Need to Regulate Emerging High Seas Uses" (2008) 23 Int'1 J. Marine \& Coastal L. 297.

Steve Rayner, Clare Heyward, Tim Kruger, Nick Pidgeon, Catherine Redgwell and Julian Savulescu "The Oxford Principles" (2013) 121 Climatic Change 499.

Jesse L. Reynolds and Floor Fleurke "Climate Engineering Research: A Precautionary Response to Climate Change?" (2013) 2 CCLR 101.

Karen Scott "The Day After Tomorrow: Ocean $\mathrm{CO} 2$ Sequestration and the Future of climate Change" (2005) 18 Georgetown International Law Review 57.

Karen Scott "International Law in the Anthropocene: Responding to the Geoengineering Challenge" (2013) 34 Michigan Journal of International Law 309.

Karen N. Scott "Regulating Ocean Fertilization under International Law: The Risks" (2013) 2 CCLR 108. 
Virginia Simms "Making the Rain: Cloud Seeding, the Imminent Freshwater Crisis, and International Law” (2010) 44 Int'l Law 915.

V. Smetacek and S. W. A. Naqvi "The Next Generation of Iron Fertilization Experiments in the Southern Ocean" (2008) 366 Phil. Trans. R. Soc. A. 3947.

Erin Tanimura "Geoengineering Research Governance: Foundation, Form and Forum" (2013) 37 Environs Envtl. L. \& Pol'y J. 167.

Richard S. J. Tol "The Economic Effects of Climate Change" (2009) 23 Journal of Economic Perspectives 29.

David G. Victor "On the Regulation of Geoengineering" (2008) 24 Oxford Review of Economic Policy 322.

Gunther Wachtershauser "Evolution of the first metabolic cycles" (1990) 87 Proc. Natl. Acad. Sci. USA 200.

Robin Warner "Marine Snow Storms: Assessing the Environmental Risks of Ocean Fertilization" (2009) 4 CCLR 426.

Rex J. Zedalis "Climate Change and the National Academy of Sciences' Idea of Geoengineering: One American Academic's Perspective on First Considering the Text of Existing International Agreements" (2010) European Energy and Environmental Law Review 18.

$G$ Reports 
The Royal Society "Geoengineering the Climate: Science Governance and Uncertainty" (2009) Report.

Intergovernmental Panel on Climate Change "Climate Change 2013: The Physical Basis. Contribution of Working Group I to the Fifth Assessment Report of the Intergovernmental Panel on Climate Panel on Climate Change" (2013) Report.

\section{$H$ Other Materials}

Alfred-Wegener-Institut "LOHAFEX: An Indo-German iron fertilization experiment" $<$ http://www.awi.de/en/news/press_releases/detail/item/lohafex_an_indo_german_iron_fe rtilization_experiment_what_are_the_effects_on_the_ecology_and_carb/?cHash $=725 \mathrm{a} 5 \mathrm{~b}$ $9368>$.

Catherine Brahic "Company Plans 'Eco' Iron Dump off Galapagos" $<$ http://www.newscientist.com/article/dn12111-company-plans-eco-iron-dump-offgalapagos.html\#.VCJ9T_mSxvE $>$.

Tommy T.B. Koh, President of the Third United Nations Conference on the Law of the Sea "A Constitution for the Oceans" (6 and 11 December 1982) Oceans and Law of the Sea $<$ www.un.org $>$.

Jeff Tollefson "Ocean-fertilization Project off Canada Sparks Furore" $<$ http://www.nature.com/news/ocean-fertilization-project-off-canada-sparks-furore$1.11631>$.

United Nations Office at Geneva "Convention in the Prohibition of Military or Any Other Hostile Use of Environmental Modification Techniques (ENMOD) $<$ http://www.unog.ch/enmod $>$. 